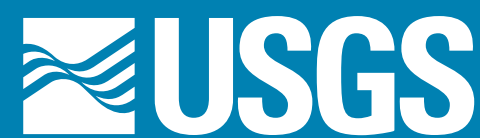

science for a changing world

Prepared in cooperation with the

KANSAS DEPARTMENT OF HEALTH AND ENVIRONMENT

Sedimentation and Occurrence and Trends of Selected

Nutrients, Other Chemical Constituents, and Diatoms

in Bottom Sediment, Fall River Lake, Southeast

Kansas, 1948-2006

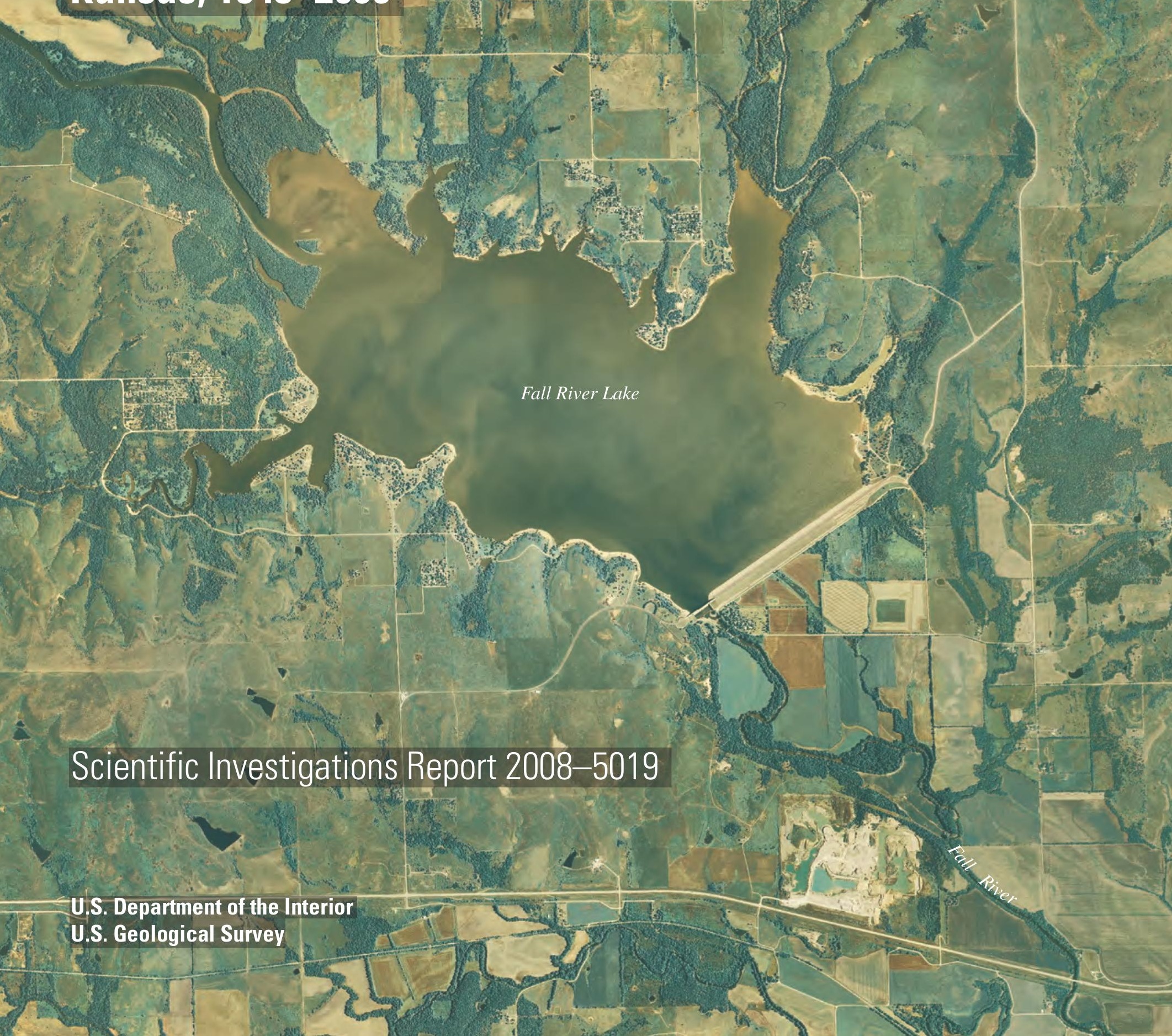


Cover. Digital ortho photography of Fall River Lake, near Fall River, Kansas, 2006 (Photography from U.S. Department of Agriculture, Farm Service Agency, Aerial Photography Field Office, Salt Lake City, Utah). 


\section{Sedimentation and Occurrence and Trends of Selected Nutrients, Other Chemical Constituents, and Diatoms in Bottom Sediment, Fall River Lake, Southeast Kansas, 1948-2006}

By Kyle E. Juracek

Prepared in cooperation with the Kansas Department of Health and Environment

Scientific Investigations Report 2008-5019 


\section{U.S. Department of the Interior DIRK KEMPTHORNE, Secretary}

\section{U.S. Geological Survey \\ Mark D. Myers, Director}

\section{U.S. Geological Survey, Reston, Virginia: 2008}

For product and ordering information:

World Wide Web: http://www.usgs.gov/pubprod

Telephone: 1-888-ASK-USGS

For more information on the USGS — the Federal source for science about the Earth, its natural and living resources, natural hazards, and the environment:

World Wide Web: http://www.usgs.gov

Telephone: 1-888-ASK-USGS

Any use of trade, product, or firm names is for descriptive purposes only and does not imply endorsement by the U.S. Government.

Although this report is in the public domain, permission must be secured from the individual copyright owners to reproduce any copyrighted materials contained within this report.

Suggested citation:

Juracek, K.E., 2008, Sedimentation and occurrence and trends of selected nutrients, other chemical constituents, and diatoms in bottom sediment, Fall River Lake, southeast Kansas, 1948-2006: U.S. Geological Survey Scientific Investigations Report 2008-5019, 29 p. 


\section{Contents}

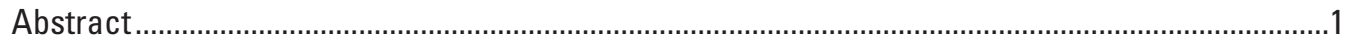

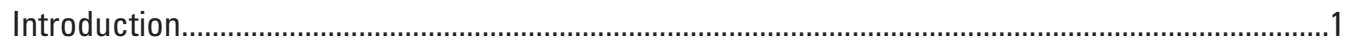

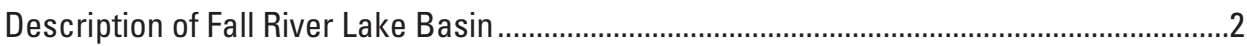

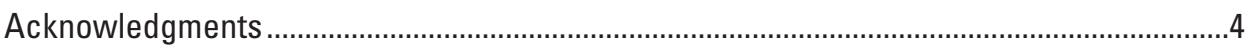

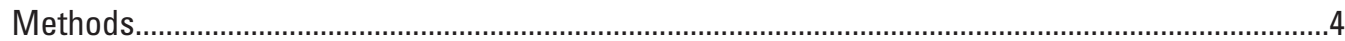

Estimation of Bottom-Sediment Volume, Mass, Mean Annual Net Deposition, and Mean Annual Net Yield $\ldots 4$

Sediment-Core Collection and Processing ............................................................................

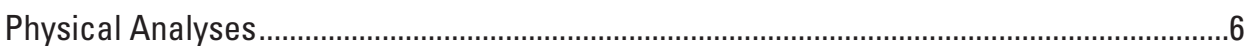

Chemical Analyses, Quality Control, and Age Dating ..........................................................

Estimation of Nutrient Loads and Yields ...............................................................................

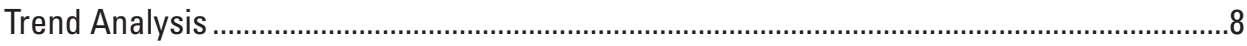

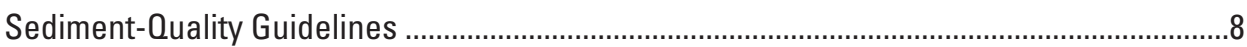

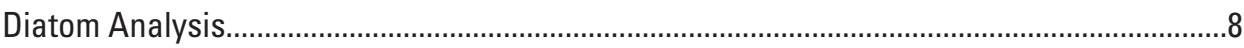

Background Information for Selected Chemical Constituents and Diatoms .........................8

Nutrients and Total Organic Carbon ....................................................................................

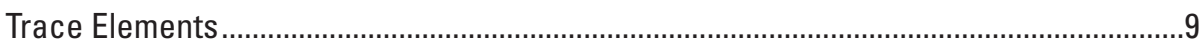

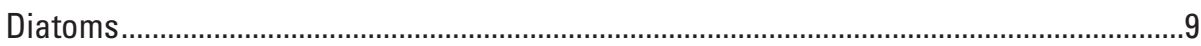

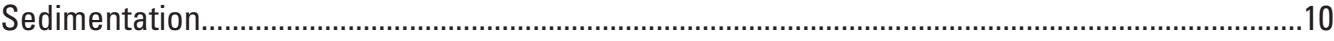

Occurrence of, and Trends in, Selected Chemical Constituents and Diatoms...............................12

Nutrients and Total Organic Carbon ................................................................................12

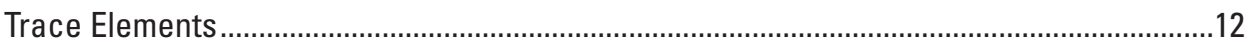

Diatoms

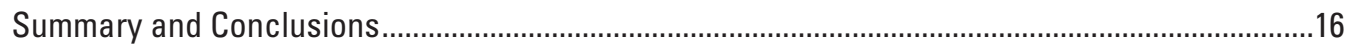

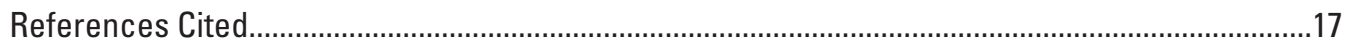

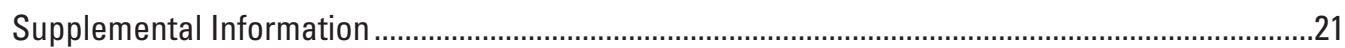

\section{Figures}

1-2. Maps showing:

1. Location of Fall River Lake Basin, Fall River Lake, and land use (1988-90) in Fall River Lake Basin, southeast Kansas ...........................................................................

2. Location of bottom-sediment coring sites in Fall River Lake, southeast Kansas .......5

3. Graphs showing variation in mean annual flow for Otter Creek at Climax, Fall River near Eureka, and Fall River at Fredonia, Kansas

4. Graph showing variation in total phosphorus concentrations with depth of bottom sediment samples collected from coring site F-2B in Fall River Lake, southeast Kansas, October 2006

5. Graph showing variation in cesium-137 activity with depth of bottom-sediment samples collected from coring site F-2B in Fall River Lake, southeast Kansas, October 2006.....15 


\section{Tables}

1. Chemical analyses performed on bottom-sediment samples from Fall River Lake, southeast Kansas

2. Relative percentage differences for constituent concentrations in split-replicate samples from bottom sediment cores from Fall River Lake, southeast Kansas.

3. Sediment-quality guidelines for selected trace elements and associated bioaccumulation index.

4. Sediment yield, precipitation, and land use for selected reservoir basins in Kansas....10

5. Results of trend tests on concentrations of selected constituents in bottom-sediment samples collected from Fall River Lake core F-2B, southeast Kansas, October 2006....13

A1. Latitude and longitude coordinates, water depth, estimated sediment thickness, length of recovered core, and estimated recovery percentage for bottom-sediment coring sites at Fall River Lake, southeast Kansas.....

A2. Estimated bulk density of bottom sediment at coring sites in Fall River Lake, southeast Kansas

A3. Percentage of silt and clay and constituent concentrations for bottom-sediment samples collected from core F-2B at coring site F-2 in Fall River Lake, southeast Kansas, October 2006

A4. Percentage of silt and clay and constituent concentrations for bottom-sediment samples collected from coring site F-4 in Fall River Lake, southeast Kansas, October 2006

A5. Percentage of silt and clay and constituent concentrations for bottom-sediment samples collected from coring site F-5 in Fall River Lake, southeast Kansas, October 2006

A6. Diatom species, number of valves counted, and relative percentage abundance in bottom-sediment samples collected from core F-2B at coring site F-2 in Fall River Lake, southeast Kansas, October 2006 


\section{Conversion Factors, Abbreviations, and Datum}

\begin{tabular}{|c|c|c|}
\hline Multiply & By & To obtain \\
\hline \multicolumn{3}{|c|}{ Length } \\
\hline centimeter $(\mathrm{cm})$ & 0.3937 & inch (in.) \\
\hline foot $(\mathrm{ft})$ & 0.3048 & meter $(\mathrm{m})$ \\
\hline inch (in.) & 2.54 & centimeter $(\mathrm{cm})$ \\
\hline mile (mi) & 1.609 & kilometer $(\mathrm{km})$ \\
\hline millimeter $(\mathrm{mm})$ & 0.03937 & inch (in.) \\
\hline \multicolumn{3}{|c|}{ Area } \\
\hline acre & 4,047 & square meter $\left(\mathrm{m}^{2}\right)$ \\
\hline acre & 0.4047 & hectare (ha) \\
\hline acre & 0.004047 & square kilometer $\left(\mathrm{km}^{2}\right)$ \\
\hline square foot $\left(\mathrm{ft}^{2}\right)$ & 0.09290 & square meter $\left(\mathrm{m}^{2}\right)$ \\
\hline square mile $\left(\mathrm{mi}^{2}\right)$ & 259.0 & hectare (ha) \\
\hline square mile $\left(\mathrm{mi}^{2}\right)$ & 2.590 & square kilometer $\left(\mathrm{km}^{2}\right)$ \\
\hline \multicolumn{3}{|c|}{ Volume } \\
\hline acre-foot (acre-ft) & 1,233 & cubic meter $\left(\mathrm{m}^{3}\right)$ \\
\hline cubic centimeter $\left(\mathrm{cm}^{3}\right)$ & 0.06102 & cubic inch $\left(\mathrm{in}^{3}\right)$ \\
\hline cubic foot $\left(\mathrm{ft}^{3}\right)$ & 0.02832 & cubic meter $\left(\mathrm{m}^{3}\right)$ \\
\hline \multicolumn{3}{|c|}{ Flow rate } \\
\hline cubic foot per second $\left(\mathrm{ft}^{3} / \mathrm{s}\right)$ & 0.02832 & cubic meter per second $\left(\mathrm{m}^{3} / \mathrm{s}\right)$ \\
\hline \multicolumn{3}{|c|}{ Mass } \\
\hline $\operatorname{gram}(\mathrm{g})$ & 0.03527 & ounce $(\mathrm{oz})$ \\
\hline milligram per liter (mg/L) & 1.0 & part per million (ppm) \\
\hline pound (lb) & 0.4536 & kilogram (kg) \\
\hline \multicolumn{3}{|c|}{ Density } \\
\hline pound per cubic foot $\left(\mathrm{lb} / \mathrm{ft}^{3}\right)$ & 16.02 & kilogram per cubic meter $\left(\mathrm{kg} / \mathrm{m}^{3}\right)$ \\
\hline
\end{tabular}

Temperature in degrees Celsius $\left({ }^{\circ} \mathrm{C}\right)$ may be converted to degrees Fahrenheit $\left({ }^{\circ} \mathrm{F}\right)$ as follows:

$$
{ }^{\circ} \mathrm{F}=\left(1.8 x^{\circ} \mathrm{C}\right)+32
$$

Temperature in degrees Fahrenheit $\left({ }^{\circ} \mathrm{F}\right)$ may be converted to degrees Celsius $\left({ }^{\circ} \mathrm{C}\right)$ as follows:

$$
{ }^{\circ} \mathrm{C}=\left({ }^{\circ} \mathrm{F}-32\right) / 1.8
$$

Horizontal coordinate information is referenced to the North American Datum of 1983 (NAD 83). 



\title{
Sedimentation and Occurrence and Trends of Selected Nutrients, Other Chemical Constituents, and Diatoms in Bottom Sediment, Fall River Lake, Southeast Kansas, 1948-2006
}

\author{
By Kyle E. Juracek
}

\begin{abstract}
A combination of available bathymetric-survey information and bottom-sediment coring was used to investigate sedimentation and the occurrence of selected nutrients (total nitrogen and total phosphorus), organic and total carbon, 25 trace elements, diatoms, and the radionuclide cesium-137 in the bottom sediment of Fall River Lake, southeast Kansas. The total estimated volume and mass of bottom sediment deposited from 1948 through 2006 in the original conservation pool of the reservoir was 470 million cubic feet and 18.8 billion pounds, respectively. The estimated sediment volume occupied about 36 percent of the original conservation-pool, water-storage capacity of the reservoir. Mean annual net sediment deposition since 1948 in the original conservation pool of the reservoir was estimated to be 324 million pounds per year. Mean annual net sediment yield from the Fall River Lake Basin was estimated to be 585,000 pounds per square mile per year.
\end{abstract}

The mean annual net loads of total nitrogen and total phosphorus deposited in the bottom sediment of Fall River Lake were estimated to be 648,000 pounds per year and 267,000 pounds per year, respectively. The estimated mean annual net yields of total nitrogen and total phosphorus from the Fall River Lake Basin were 1,170 pounds per square mile per year and 480 pounds per square mile per year, respectively. Throughout the history of Fall River Lake, total nitrogen and total phosphorus concentrations in the deposited sediment were relatively uniform.

Trace element concentrations in the bottom sediment of Fall River Lake generally were uniform over time. Arsenic, chromium, nickel, and zinc concentrations typically exceeded the threshold-effects guidelines, which represent the concentrations above which toxic biological effects occasionally occur. Trace element concentrations did not exceed the probable-effects guidelines (available for eight trace elements), which represent the concentrations above which toxic biological effects usually or frequently occur.
Diatom occurrence in the bottom sediment of Fall River Lake was dominated by the species Aulacoseira granulata, which is an indicator of eutrophic (nutrient-rich) conditions. The abundance of the diatom Aulacoseira granulata, combined with cyanobacteria evidence and historical water-quality data, indicated that Fall River Lake likely has been eutrophic throughout much of its history.

\section{Introduction}

Reservoirs provide many benefits including flood control, water supply, recreation, and habitat for fish and wildlife. The effective management of reservoirs requires several types of information including water quality, sedimentation, and sediment quality.

Water-quality information is necessary for determining the suitability of the water in a reservoir in meeting various needs. Trends in water quality are useful for describing the overall effect of human activity in a reservoir basin, for providing an indication of the effectiveness of regulatory decisions and changes in land-management practices, and for providing a warning of potential future water-quality problems.

The volume and quality of sediment deposited in a reservoir also are important. Sedimentation affects the useful life and the aesthetic quality of a reservoir. Sediment quality is an important environmental concern because sediment may act as a sink for water-quality constituents and, under certain conditions, as a source of constituents to the overlying water column and biota (Baudo and others, 1990; Zoumis and others, 2001). Sediment-associated constituents of concern include nutrients (for example, phosphorus), trace elements, and several pesticides. Once in the food chain, some sediment-derived constituents may pose an even greater concern because of bioaccumulation (Pais and Jones, 1997; Smol, 2002). An analysis of reservoir bottom sediment can provide historical information on sediment deposition as well as the occurrence of sedimentbound constituents. Such information may be used to partly 
reconstruct historical sediment-quality and water-quality records and to determine a present-day baseline with which to evaluate long-term changes in reservoir sediment and water quality that may be related to changes in human activity in the basin (Charles and Hites, 1987; Van Metre and Callender, 1996; Van Metre and Mahler, 2004).

Fall River Lake is a Federal impoundment on the Fall River in Greenwood County, southeast Kansas (fig. 1). The reservoir officially was completed in May 1949 by the U.S. Army Corps of Engineers (USCOE) with an original design life of 50 years. Water storage began in August 1948. The reservoir is used for several purposes including flood control, water supply, recreation, low-flow regulation, water-quality control, and fish and wildlife (Gary Simmons, U.S. Army Corps of Engineers, written commun., 2007).

In 2006, Fall River Lake was listed under Section 303(d) of the Federal Clean Water Act of 1972 for eutrophication (as well as dissolved oxygen and siltation) (Kansas Department of Health and Environment, 2007). A eutrophic lake contains nutrient-rich water and supports high biotic productivity (Cole, 1994). Typically, eutrophic lakes support algal growth that, if excessive, can cause taste-and-odor problems for water suppliers. Also, excessive algal growth may be detrimental to aquatic life and discourage recreational use of a lake.

The 303(d) list is a priority list that identifies water bodies that do not meet water-quality standards that are based on the use of the water bodies. For each impaired water body on the 303(d) list, a State is required by the Federal Clean Water Act to develop a total maximum daily load (TMDL), which is an estimate of the maximum pollutant load (material transported during a specified time period) from point and nonpoint sources that a receiving water can accept without exceeding water-quality standards (U.S. Environmental Protection Agency, 1991).

To provide information in support of the TMDL process, a 2-year study by the U.S. Geological Survey (USGS), in cooperation with the Kansas Department of Health and Environment (KDHE), was begun in 2006 to investigate sedimentation in Fall River Lake as well as the deposition of selected chemical constituents and diatoms. The specific study objectives were to:

1. Estimate the volume, mass, mean annual net deposition, and mean annual net yield of sediment for the reservoir;

2. Determine the occurrence and trends of selected waterquality constituents in the bottom sediment of the reservoir;

3. Determine the mean annual net loads and yields of selected nutrients from the reservoir basin; and

4. Determine the occurrence and relative abundance of diatoms in the bottom sediment as an indication of eutrophication over the life of the reservoir.

The purpose of this report is to present the results of the USGS study to estimate sedimentation and to determine the occurrence of, and temporal trends in, selected chemical constituents and diatoms in the bottom sediment of Fall River Lake for 1948 through 2006. Study objectives were accomplished by using available bathymetric information from USCOE and by the collection and analysis of sediment cores in October 2006. Results presented in this report will assist KDHE in the evaluation, development, and implementation of TMDLs for constituents determined to contribute to waterquality impairment in the reservoir. From a national perspective, the methods and results presented provide guidance and perspective for future reservoir studies concerned with the issues of sedimentation and water quality.

\section{Description of Fall River Lake Basin}

The Fall River Lake Basin is an area of about $554 \mathrm{mi}^{2}$ that drains part of southeast Kansas (fig. 1). In 1948, Fall River Lake had an original surface area of about 2,620 acres and a water-storage capacity of about 30,400 acre-ft at the conservation-pool elevation of $948.5 \mathrm{ft}$ above the National Geodetic Vertical Datum (NGVD) of 1929. In 1990, the surface area and water-storage capacity at the conservation-pool elevation were about 2,330 acres and 22,600 acre-ft, respectively (Sarah Harris, U.S. Army Corps of Engineers, written commun., 2006). The decreases in surface area and storage capacity are the result of ongoing sedimentation. In addition to the Fall River, several small tributaries contribute flow directly to Fall River Lake (fig. 1).

The Fall River Lake Basin is located in the Osage Plains Section of the Central Lowland physiographic province (Fenneman, 1946; Schoewe, 1949). Within the Osage Plains Section, most of the basin is located in the Osage Cuestas physiographic division with the exception of the extreme western part of the basin that is located in the Flint Hills Upland. The Osage Cuestas generally consist of a series of irregular northeast-southwest trending escarpments between which are flat to gently rolling plains. The topography of the Flint Hills Upland is characterized as gently rolling. Throughout the Osage Plains, the underlying bedrock is primarily limestone and shale of Permian and Pennsylvanian age (Schoewe, 1949). Slopes in the basin range from nearly level to gently sloping on the flood plains and from gently sloping to steep in the uplands. Generally, slopes are less than 10 percent but locally may be as steep as 20 to 30 percent (U.S. Department of Agriculture, Soil Conservation Service, 1982).

Long-term mean annual precipitation at Eureka, located in the central part of the Fall River Lake Basin (fig. 1), is about 38 in. (period of record 1954-2005) (High Plains Regional Climate Center, 2007). Most of the annual precipitation is received during the growing season (generally April-September).

Land use (1988-90) in the Fall River Lake Basin is mostly agricultural with grassland accounting for about 90 percent of the basin. Cropland and woodland account for about 4 and 3 percent of the basin, respectively. Urban land 


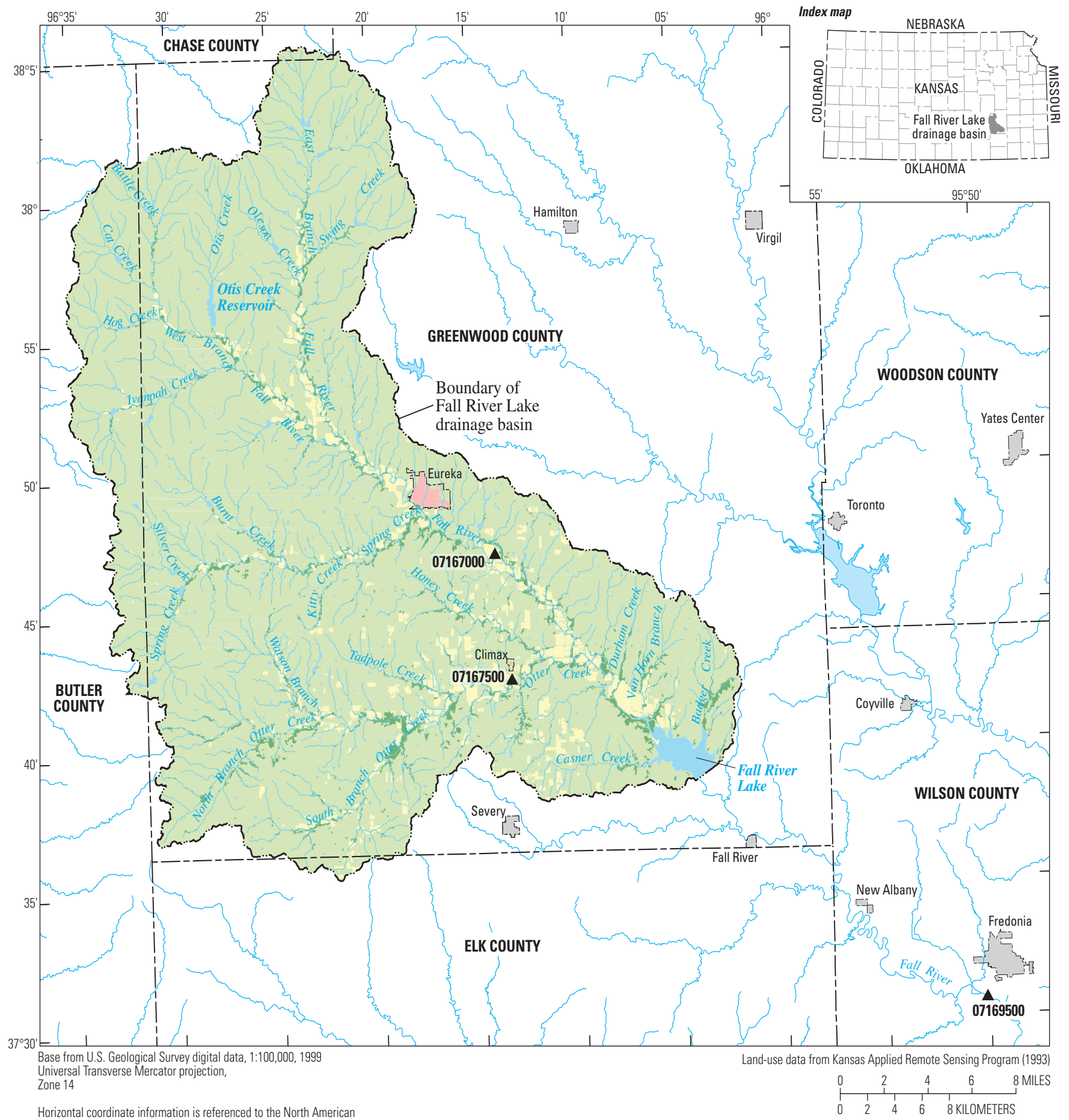

Datum of 1983 (NAD 83 )

EXPLANATION

Land use

$\square$ Cropland $\square$ Urban
$\square$ Grassland $\square$ Water
Woodland $\square$ Other

$07169500 \triangle$ U.S. Geological Survey streamflowgaging station and number

Figure 1. Location of Fall River Lake Basin, Fall River Lake, and land use (1988-90) in the Fall River Lake Basin, southeast Kansas (source of land-use data: Kansas Applied Remote Sensing Program, 1993). 
use occupies less than 1 percent of the basin (fig. 1) (Kansas Applied Remote Sensing Program, 1993).

\section{Acknowledgments}

This study was made possible in part by support from the Kansas Department of Health and Environment (KDHE) and the Kansas State Water Plan Fund. The author gratefully acknowledges topographic and bathymetric information provided by USCOE as well as water-quality data provided by KDHE. The author also thanks Jennifer Graham (USGS) for her assistance in interpreting the diatom and related biological information.

\section{Methods}

The objectives of this study were accomplished using available and newly collected information. Available information included original and updated reservoir water-storage capacity data from USCOE and historical water-quality data from KDHE. New information was obtained through the collection and analysis of multiple bottom-sediment cores.

\section{Estimation of Bottom-Sediment Volume, Mass, Mean Annual Net Deposition, and Mean Annual Net Yield}

The bottom-sediment volume (sediment plus pore water and gases) in the conservation pool of Fall River Lake was estimated by subtracting the updated water-storage capacity from the original water-storage capacity for the reservoir. The water-storage capacity originally was estimated by USCOE in 1948 with subsequent updates in 1973 and 1990. Thus, the bottom-sediment volume was estimated as the 1948 waterstorage capacity minus the 1990 water-storage capacity. The mean annual volume of sediment deposited (1948-1990) was computed as the total bottom-sediment volume divided by the number of years of deposition (42 years). Then, to provide an estimate of the current (2006) bottom-sediment volume, the mean annual volume of sediment deposited (1948-1990) was multiplied by the age of the reservoir (58 years). A partial bathymetric survey completed by USGS in October 2006 indicated that using the mean annual volume of sediment deposited (1948-1990) to estimate the total current (2006) bottom-sediment volume was reasonable.

Bottom-sediment mass was estimated by multiplying the current (2006) bottom-sediment volume by the representative bulk density. The representative bulk density for the reservoir was computed as the average of the mean bulk densities that were determined from sediment cores (see discussion in "Physical Analyses" section later in this report). Because bulk density varies with location and the representative bulk density accounts only for three sites in the reservoir, the estimated total bottom-sediment mass has a potential error of unknown magnitude.

The mean annual mass of sediment (dry weight) deposited was estimated as the bottom-sediment mass divided by the age of the reservoir. Mean annual sediment yield from the reservoir basin was estimated by dividing the mean annual mass of sediment deposited by the area of the basin. Because sediment losses are not accounted for (for example, as a result of reservoir outflow), the estimated mean annual sediment deposition and yield represent net, rather than total, values. However, given that sediment trap efficiencies for large reservoirs typically are greater than 90 percent (Brune, 1953; Vanoni, 2006), the sediment losses likely are minimal.

\section{Sediment-Core Collection and Processing}

Bottom-sediment cores were collected in October 2006 at three sites (fig. 2) within Fall River Lake. Two cores were collected at site $\mathrm{F}-2$ to provide sufficient sediment mass for planned physical, chemical, and diatom analyses. Of the four cores collected at Fall River Lake, one was used for chemical and diatom analyses (core B at site F-2, hereafter referred to as core $\mathrm{F}-2 \mathrm{~B}$ ), two were used for chemical analysis and bulk-density determinations (cores F-4 and F-5), and one was used for bulk-density determinations only (core A at site F-2, hereafter referred to as core F-2A) (fig. 2).

The cores were collected from a pontoon boat using a gravity corer. The liner used for all cores was cellulose acetate butyrate transparent tubing with a 2.625 -in. inside diameter. The latitude and longitude for each coring site, obtained using GPS technology, are provided in table A1 in the "Supplemental Information" section at the back of this report.

When using a gravity corer, a phenomenon referred to as "core shortening" occurs that results in a recovered sediment core that may be only about one-half of the actual thickness of the sediment penetrated (Emery and Hulsemann, 1964). Core shortening is caused by the friction of the sediment against the inner wall of the core liner as the corer penetrates the sediment (Emery and Hulsemann, 1964; Hongve and Erlandsen, 1979; Blomqvist, 1985; Blomqvist and Bostrom, 1987). In "normal" lake-bottom sediment, which is characterized by uniform texture with decreasing water content at depth, core shortening results in a core that provides a thinned but complete representation of all of the sediment layers that were penetrated (Emery and Hulsemann, 1964; Hongve and Erlandsen, 1979).

Because of the substantial thickness of the bottom sediment at the locations cored in Fall River Lake, penetration of the entire sediment thickness was not achieved for all cores. In fact, complete penetration was achieved only for core F-2B as evidenced by differences in moisture content, texture, and organic matter content at the boundary between the sediment deposited in the reservoir and the underlying original (prereservoir) land-surface material. Penetration was believed to be nearly complete for nearby core F-2A. Complete penetra- 


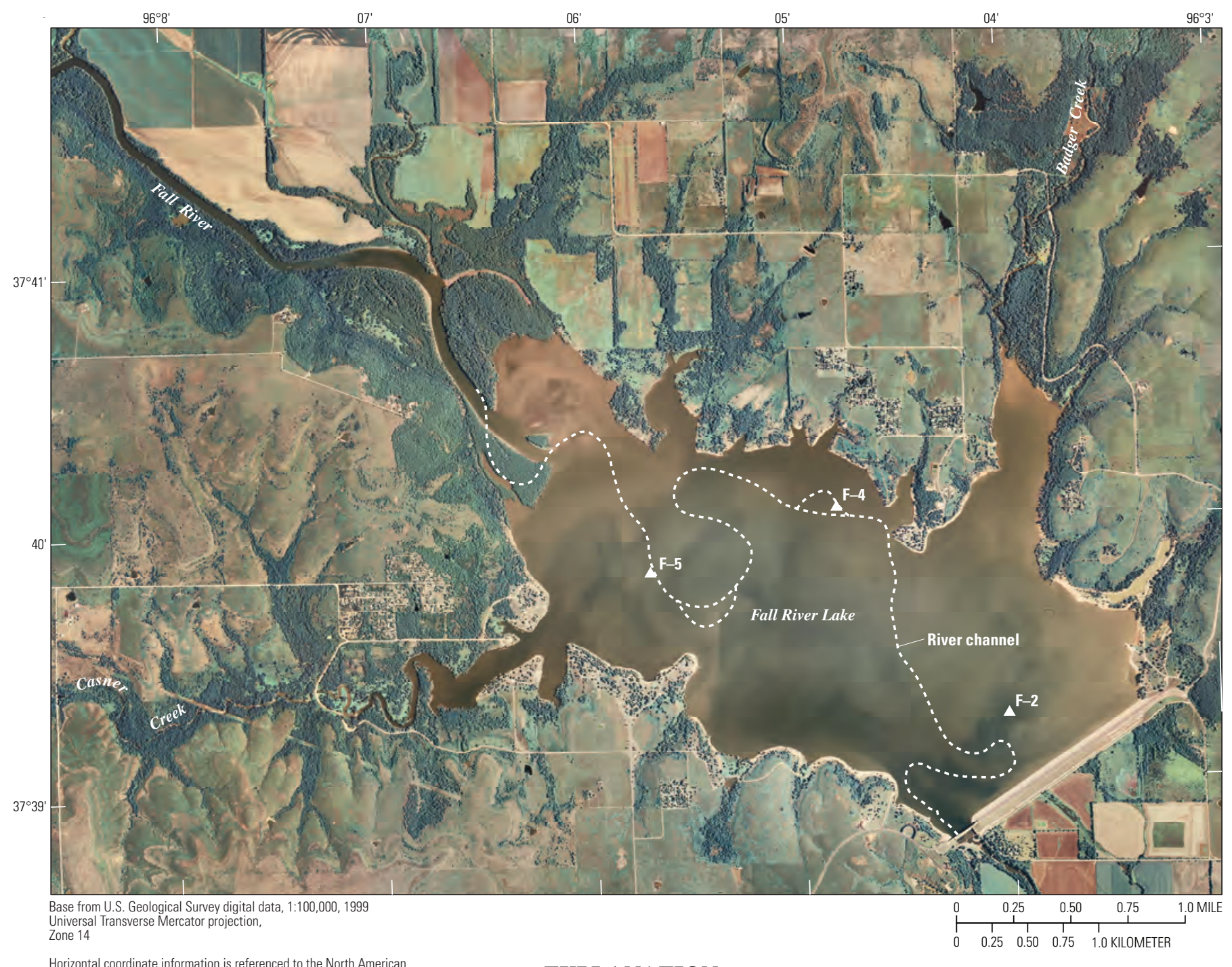

Horizontal coordinate information is referenced to the North American Datum of 1983 (NAD 83)

\section{EXPLANATION}

F-2 $\triangle$ Coring site and identifier

Figure 2. Location of bottom-sediment coring sites in Fall River Lake, southeast Kansas.

tion was not achieved for cores $\mathrm{F}-4$ and $\mathrm{F}-5$. A comparison of the length of core recovered by gravity coring to the thickness of sediment penetrated indicated that recovery was about 65 to 70 percent for core $\mathrm{F}-2 \mathrm{~B}$. Sediment thickness at site $\mathrm{F}-2$ was estimated at about $10 \mathrm{ft}$. At coring sites $\mathrm{F}-4$ and F-5, USCOE bathymetric information indicated that the sediment thickness in the submerged river channel was at least $20 \mathrm{ft}$ (on the basis of the 1990 bathymetric survey and extrapolating to 2006). For cores $\mathrm{F}-2 \mathrm{~A}, \mathrm{~F}-4$, and $\mathrm{F}-5$ it was assumed that the sediment recovered provided representative information for the entire sediment thickness at each site. Average length for the four cores collected was about $7 \mathrm{ft}$ (table A1).

The sediment cores were transported to the USGS laboratory in Lawrence, Kansas, where they were stored vertically and refrigerated (at $4-5^{\circ} \mathrm{C}$ ) until processed. The core liners were cut lengthwise in two places 180 degrees apart. The cuts were completed with a 4-in. hand-held circular saw with the blade set at a depth to minimize penetration of the sediment cores. The cores were split in half by pulling a tightly held nylon string through the length of the cores and allowing the halves to separate. Once split, the relatively undisturbed inner parts of the cores were exposed for examination and sampling. On the basis of differences in moisture content, texture, and organic matter content (for example, root hairs, sticks, seed pods, leaves), the boundary between the sediment deposited in the reservoir and the underlying original (pre-reservoir) land-surface material was determined. Typically, the bottom sediment was characterized by higher moisture content, finer texture, and little if any visible organic matter as compared to the original material. 


\section{Physical Analyses}

Physical analyses included bulk-density determinations and particle-size analyses. Cores F-2A, F-4, and F-5 from Fall River Lake were analyzed to determine bulk density. For this purpose, each core was divided into six or seven intervals of equal length. The number of intervals was dependent on the length of each core. From each interval, a 1-in. thick cylindrical volume of sediment was removed using a putty knife, weighed to the nearest 0.10 gram, oven dried at about $45^{\circ} \mathrm{C}$ for 96 hours, and reweighed. Oven drying of the sample continued as it was reweighed on a daily basis until no additional moisture loss was observed. Bulk density was computed as follows:

$$
D_{b}=m / v
$$

where $D_{b}$ is the bulk density (in grams per cubic centimeter), $m$ is the mass (dry weight) of the sample (in grams), and $v$ is the volume of the sample (in cubic centimeters). The volume for a cylindrical sample was computed as:

$$
v=h\left(\pi d^{2} / 4\right)
$$

where $v$ is the volume of the sample (in cubic centimeters), $h$ is the height (length) of the sample (in centimeters), and $d$ is the diameter of the sample (in centimeters) (Gordon and others, 1992). In all, 20 bulk-density determinations were completed at the USGS laboratory in Lawrence, Kansas (table A2 at the back of this report).

Results for all sampled intervals were averaged to determine the mean bulk density for each core. The bulk densities then were converted to pounds per cubic foot for use in subsequent computations. The representative bulk density was com- puted as the average of the mean bulk densities determined for the three individual cores.

Particle-size analysis was performed to determine the percentage of sand (that is, particles larger than $0.063 \mathrm{~mm}$ in diameter) and silt and (or) clay (that is, particles smaller than $0.063 \mathrm{~mm}$ in diameter) in the sediment cores. The sediment samples used for constituent analyses also were used for particle-size analyses. The particle-size analyses were completed at the USGS Sediment Trace Element Partitioning Laboratory in Atlanta, Georgia, according to the methods presented in Guy (1969) and Grosbois and others (2001).

\section{Chemical Analyses, Quality Control, and Age Dating}

The number of samples for chemical analysis removed from each core was dependent on the length of the core, the intended use of the core, and the amount of material required for analyses. In all cases, care was taken to avoid sampling the sediment that came into contact with the core liner and the saw blade. Each core was divided into multiple intervals of equal length. An approximately equal volume of sediment (defined as the space occupied by the sediment particles, water, and gases as measured in cubic units) was removed lengthwise from both halves of each interval and combined using a plastic spatula. The combined sediment volume for each interval was homogenized and sampled for subsequent chemical analyses.

The sediment samples were analyzed for nutrients (total nitrogen and total phosphorus), organic and total carbon, and 25 trace elements. A complete list of the constituents for which analyses were performed is provided in table 1 . Core F-2B was divided into 12 intervals of equal length, sampled, and analyzed to assess trends in constituent deposition during

Table 1. Chemical analyses performed on bottom-sediment samples from Fall River Lake, southeast Kansas.

[Number in parentheses is the method reporting limit for each constituent. $\mathrm{mg} / \mathrm{kg}$, milligrams per kilogram; \%, percent dry weight;

\begin{tabular}{|c|c|c|c|}
\hline \multicolumn{4}{|c|}{ Nutrients } \\
\hline Total nitrogen $(100 \mathrm{mg} / \mathrm{kg})$ & \multicolumn{3}{|l|}{ Total phosphorus $(50 \mathrm{mg} / \mathrm{kg}$ ) } \\
\hline \multicolumn{4}{|c|}{ Carbon } \\
\hline Carbon, total organic $(0.1 \%)$ & \multicolumn{3}{|l|}{ Carbon, total $(0.1 \%)$} \\
\hline \multicolumn{4}{|c|}{ Trace elements } \\
\hline Aluminum $(0.1 \%)$ & Cobalt $(1.0 \mathrm{mg} / \mathrm{kg})$ & Nickel $(1.0 \mathrm{mg} / \mathrm{kg})$ & Titanium $(0.01 \%)$ \\
\hline Antimony $(0.1 \mathrm{mg} / \mathrm{kg})$ & Copper $(1.0 \mathrm{mg} / \mathrm{kg})$ & Selenium $(0.1 \mathrm{mg} / \mathrm{kg})$ & Uranium $(50$ mg/kg) \\
\hline Arsenic $(0.1 \mathrm{mg} / \mathrm{kg})$ & Iron $(0.1 \%)$ & Silver $(0.5 \mathrm{mg} / \mathrm{kg})$ & Vanadium $(1.0 \mathrm{mg} / \mathrm{kg})$ \\
\hline Barium $(1.0 \mathrm{mg} / \mathrm{kg})$ & Lead (1.0 mg/kg) & Strontium $(1.0 \mathrm{mg} / \mathrm{kg})$ & Zinc $(1.0$ mg/kg) \\
\hline Beryllium $(0.1 \mathrm{mg} / \mathrm{kg})$ & Lithium $(1.0 \mathrm{mg} / \mathrm{kg})$ & Sulfur $(0.1 \%)$ & \\
\hline Cadmium $(0.1 \mathrm{mg} / \mathrm{kg})$ & Manganese $(10.0 \mathrm{mg} / \mathrm{kg})$ & Thallium $(50 \mathrm{mg} / \mathrm{kg})$ & \\
\hline Chromium $(1.0 \mathrm{mg} / \mathrm{kg})$ & Molybdenum (1.0 mg/kg) & $\operatorname{Tin}(1.0 \mathrm{mg} / \mathrm{kg})$ & \\
\hline \multicolumn{4}{|c|}{ Radionuclide } \\
\hline Cesium-137 (0.05 pCi/g) & & & \\
\hline
\end{tabular}
$\mathrm{pCi} / \mathrm{g}$, picocuries per gram] 
the life of the reservoir. Cores $\mathrm{F}-4$ and $\mathrm{F}-5$ were divided into 3 intervals of equal length, sampled, and analyzed for constituents. Constituent analyses of bottom-sediment samples were performed at the USGS Sediment Trace Element Partitioning Laboratory in Atlanta, Georgia. Analyses of sediment samples for total nitrogen and carbon concentrations were performed using the methods described by Horowitz and others (2001). Analyses for total phosphorus and trace elements were performed using the methods described by Fishman and Friedman (1989), Arbogast (1996), and Briggs and Meier (1999).

Quality control for the chemical analyses of sediment samples was provided by an evaluation of variability that involved an analysis of split-replicate samples collected from Fall River Lake. Split-replicate samples were analyzed for cores $\mathrm{F}-4$ and $\mathrm{F}-5$. For each core, a representative volume of sediment was removed, homogenized, and sampled twice. Both samples were analyzed for the various constituents. The relative percentage difference between the replicate sample concentrations was computed as:

$$
D_{r p}=[|C 1-C 2| /(C 1+C 2)] * 100,
$$

where $D_{r p}$ is the relative percentage difference, $C l$ is the first replicate sample concentration, and $C 2$ is the second replicate sample concentration.

The relative percentage differences computed for the constituents detected in the split-replicate samples are provided in table 2 . With the exception of tin, analytical variability was minimal with mean relative percentage differences less than 4 percent. Tin had a mean relative percentage difference of 22.2 percent.

Age dating of the bottom sediment was accomplished by determining the activity of cesium- $137\left({ }^{137} \mathrm{Cs}\right) \cdot{ }^{137} \mathrm{Cs}$ is a radioactive isotope that is a by-product of above-ground nuclear weapons testing. Measurable activity of this isotope first appeared in the atmosphere in about 1952, peaked during 1963-64, and has since declined (Ritchie and McHenry, 1990). Measurable activity in soils began about 1954 (Wise, 1980). ${ }^{137} \mathrm{Cs}$ is an effective marker for age dating bottom sediment in reservoirs constructed before 1963-64. It also can be used to demonstrate that the sediment is relatively undisturbed if the 1963-64 peak is well-defined and a generally uniform, exponential decrease in ${ }^{137} \mathrm{Cs}$ activity follows the peak (Van Metre and others, 1997). Age dating of sediment using ${ }^{137} \mathrm{Cs}$ was attempted for Fall River Lake cores F-2B and F-5. Analysis of sediment samples for ${ }^{137} \mathrm{Cs}$ activity was performed at the USGS Florida Integrated Science Center in St. Petersburg, Florida, using gamma-ray spectrometry (Holmes and others, 2001).

\section{Estimation of Nutrient Loads and Yields}

The mean annual load and yield of total nitrogen (TN) and total phosphorus (TP) was estimated for Fall River Lake for the period 1948 to 2006. For each nutrient, mean annual
Table 2. Relative percentage differences for constituent concentrations in split-replicate samples from bottom sediment cores from Fall River Lake, southeast Kansas.

[Location of coring sites shown in figure 2. --, not calculated because constituent was not detected in one or both of the split-replicate samples]

\begin{tabular}{|c|c|c|c|}
\hline \multirow[t]{2}{*}{ Constituent } & \multicolumn{3}{|c|}{ Relative percentage difference } \\
\hline & $\mathrm{F}-4$ & $\mathbf{F}-\mathbf{5}$ & Mean \\
\hline \multicolumn{4}{|c|}{ Nutrients } \\
\hline Total nitrogen & 0 & 0 & 0 \\
\hline Total phosphorus & 0 & .7 & .4 \\
\hline \multicolumn{4}{|c|}{ Carbon } \\
\hline Carbon, total organic & 0 & 0 & 0 \\
\hline Carbon, total & 2.2 & 0 & 1.1 \\
\hline \multicolumn{4}{|c|}{ Trace elements } \\
\hline Aluminum & 0 & 6 & .3 \\
\hline Antimony & 0 & 7.7 & 3.9 \\
\hline Arsenic & 0 & 1.5 & .8 \\
\hline Barium & 0 & 0 & 0 \\
\hline Beryllium & 1.8 & 0 & .9 \\
\hline Cadmium & 0 & 0 & 0 \\
\hline Chromium & .5 & .6 & .6 \\
\hline Cobalt & 0 & 0 & 0 \\
\hline Copper & 0 & 2.1 & 1.1 \\
\hline Iron & 0 & 0 & 0 \\
\hline Lead & 0 & 1.8 & .9 \\
\hline Lithium & .8 & 0 & .4 \\
\hline Manganese & 0 & 6 & .3 \\
\hline Molybdenum & -- & -- & -- \\
\hline Nickel & 1.2 & 1.4 & 1.3 \\
\hline Selenium & 0 & 0 & 0 \\
\hline Silver & -- & -- & -- \\
\hline Strontium & 0 & 0 & 0 \\
\hline Sulfur & 0 & 0 & 0 \\
\hline Thallium & -- & -- & -- \\
\hline Tin & 11.1 & 33.3 & 22.2 \\
\hline Titanium & 0 & 2.0 & 1.0 \\
\hline Uranium & -- & -- & -- \\
\hline Vanadium & 0 & 0 & 0 \\
\hline Zinc & 0 & 0 & 0 \\
\hline
\end{tabular}


load was estimated as the representative sediment concentration multiplied by the mean annual mass of sediment deposited in the reservoir. The representative sediment concentration was computed as the median of the sample intervals analyzed for cores F-2B, F-4, and F-5.

The mean annual yield for each nutrient was estimated by dividing the mean annual load by the area of the Fall River Lake Basin. Because sediment losses are not accounted for (for example, as a result of reservoir outflow), the computed loads and yields represent net, rather than total, values.

\section{Trend Analysis}

Core F-2B was used for trend analyses. This core was analyzed for nutrients, carbon, trace elements, and diatoms. The statistical significance of possible trends in constituent concentrations and diatom occurrence was determined by computing a nonparametric Spearman's rho correlation coefficient. An advantage of Spearman's rho is that, because it is based on ranks, it is more resistant to outlier effects than the more commonly used Pearson's r correlation coefficient (Helsel and Hirsch, 1992). Trends were considered to be significantly positive (constituent concentration or diatom occurrence increased toward the top of the sediment core) or negative (constituent concentration or diatom occurrence decreased toward the top of the sediment core) if the probability (twosided p-value) of rejecting a correct hypothesis (in this case, no trend) was less than or equal to 0.05 . In the results, a possible trend in constituent concentration will be considered meaningful only if the change in constituent concentration is beyond the variability that could be explained by analytical variance (defined here as the mean constituent concentration in the sediment core plus or minus 10 percent).

\section{Sediment-Quality Guidelines}

The U.S. Environmental Protection Agency (USEPA) has adopted nonenforceable sediment-quality guidelines (SQGs) in the form of level-of-concern concentrations for several trace elements (U.S. Environmental Protection Agency, 1997). These level-of-concern concentrations were derived from biological-effects correlations made on the basis of paired onsite and laboratory data to relate incidence of adverse biological effects in aquatic organisms to dry-weight sediment concentrations. Two such level-of-concern guidelines adopted by USEPA are referred to as the threshold-effects level (TEL) and the probable-effects level (PEL). The TEL is assumed to represent the concentration below which toxic biological effects rarely occur. In the range of concentrations between the TEL and PEL, toxic effects occasionally occur. Toxic effects usually or frequently occur at concentrations above the PEL.

USEPA cautions that the TEL and PEL guidelines are intended for use as screening tools for possible hazardous levels of chemicals and are not regulatory criteria. This cautionary statement is made because, although biological-effects correlation identifies level-of-concern concentrations associated with the likelihood of adverse organism response, the comparison may not demonstrate that a particular chemical is solely responsible. In fact, biological-effects correlations may not indicate direct cause-and-effect relations because sediments may contain a mixture of chemicals that contribute to the adverse effects to some degree. Thus, for any given site, these guidelines may be over- or underprotective (U.S. Environmental Protection Agency, 1997).

MacDonald and others (2000) developed consensusbased SQGs that were computed as the geometric mean of several previously published SQGs. The consensus-based SQGs consist of a threshold-effect concentration (TEC) and a probable-effect concentration (PEC). The TEC represents the concentration below which adverse effects are not expected to occur, whereas the PEC represents the concentration above which adverse effects are expected to occur more often than not. An evaluation of the reliability of the SQGs indicated that most of the individual TECs and PECs provide an accurate basis for predicting the presence or absence of sediment toxicity (MacDonald and others, 2000).

A comparison of the two SQGs indicated that the differences were generally small (table 3). The largest difference was for the zinc PEL and PEC. In this case, the PEC (459 mg/kg) was about 69 percent larger than the PEL (271 mg/kg). For this study, the SQGs used were selected to provide a less-stringent assessment. Thus, for each trace element for which SQGs were available, the larger of the two options for threshold effects and probable effects was selected for the purpose of assessing sediment quality (see shaded values in table 3). In this report, the options used to assess sediment quality are referred to as the threshold-effects guideline and the probable-effects guideline.

\section{Diatom Analysis}

Analysis of the sediment samples for diatoms was performed by Dr. Yangdong Pan, Portland State University, Portland, Oregon. Analyses for diatoms were performed using equipment and methods described by Acker and others (2002), Krammer and Lange-Bertalot (1986, 1988, 1991a, 1991b), and Patrick and Reimer (1966, 1975). Core F-2B was analyzed for diatoms using the same 12 intervals that were analyzed for constituents.

\section{Background Information for Selected Chemical Constituents and Diatoms}

\section{Nutrients and Total Organic Carbon}

Nutrients, such as nitrogen and phosphorus, are necessary for growth and reproduction of plants. In most freshwater environments, phosphorus is the principal limiting factor for 
Table 3. Sediment-quality guidelines for selected trace elements and associated bioaccumulation index.

\begin{tabular}{|c|c|c|c|c|c|}
\hline \multirow[b]{2}{*}{ Trace element } & \multicolumn{2}{|c|}{ USEPA (1997) } & \multicolumn{2}{|c|}{$\begin{array}{l}\text { MacDonald and others } \\
\text { (2000) }\end{array}$} & \multirow[t]{2}{*}{$\begin{array}{l}\text { Bio-accumu- } \\
\text { lation index }\end{array}$} \\
\hline & TEL & PEL & TEC & PEC & \\
\hline Arsenic & 7.24 & 41.6 & 9.79 & 33.0 & moderate \\
\hline Cadmium & .676 & 4.21 & .99 & 4.98 & moderate \\
\hline Chromium & 52.3 & 160 & 43.4 & 111 & moderate \\
\hline Copper & 18.7 & 108 & 31.6 & 149 & high \\
\hline Lead & 30.2 & 112 & 35.8 & 128 & moderate \\
\hline Nickel & 15.9 & 42.8 & 22.7 & 48.6 & moderate \\
\hline Silver & .733 & 1.77 & -- & -- & moderate \\
\hline Zinc & 124 & 271 & 121 & 459 & high \\
\hline
\end{tabular}

${ }^{1}$ Bioaccumulation index information for trace elements from Pais and Jones (1997).

primary production (Hakanson and Jansson, 1983; Wetzel, 2001). If phosphorus concentrations are too large, algal growth may become excessive and cause taste-and-odor problems for water suppliers. Additionally, excessive algal growth may be detrimental to aquatic life and discourage recreational use of a lake. Major human-related sources of nutrients include fertilizer application, livestock production, and sewage-treatment plants.

Total organic carbon (TOC), an approximate determination of total organic material in a sediment sample, is important because various organic solutes can form complexes, which in turn affect trace element solubilities (Hem, 1989). The organic carbon content of sediment also is important because many contaminants specifically sorb to the organic material in sediment (Karickhoff, 1984; Horowitz, 1991).

\section{Trace Elements}

Trace elements are important determinants of sediment quality because of their potential toxicity to living organisms (Forstner and Wittmann, 1981). Trace elements may be defined as elements that typically are present in the environment in relatively low (less than 0.1 percent) concentrations (Adriano, 1986; Pais and Jones, 1997). Using this definition, most of the elements analyzed in this study may be considered trace elements. Exceptions, which are some of the abundant rock-forming elements, include aluminum and iron (Adriano, 1986).

Trace elements in sediment originate naturally from the rock and soil within a basin. Also, sediment enrichment of certain trace elements may be attributable to several human-related sources including fertilizers, liming materials, pesticides, irrigation water, animal and human wastes, coal combustion residues, leaching from landfills, mining, metal-smelting industries, and automobile emissions (Forstner and Wittmann, 1981; Davies, 1983; Adriano, 1986).

The health of living organisms is dependent on a sufficient intake of various trace elements. Many elements, such as cobalt, copper, iron, manganese, and zinc, are essential for plants, animals, and humans. Other elements, such as arsenic and chromium, are required by animals and humans but are not essential for plants. Nonessential elements for plants, animals, and humans include cadmium, mercury, and lead (Adriano, 1986; Lide, 1993; Pais and Jones, 1997).

Toxicity is a function of several factors including the type of organism, the availability of a trace element in the environment, and the potential of the trace element to bioaccumulate in organisms. The daily intake of trace elements by animals and humans may be classified as deficient, optimal, or toxic. Most, if not all, trace elements may be toxic in animals and humans if the concentrations are sufficiently large (Forstner and Wittmann, 1981; Pais and Jones, 1997; Smol, 2002). Information on the bioaccumulation index (Pais and Jones, 1997) for the trace elements with available SQGs is provided in table 3 . The bioaccumulation index indicates the relative potential of a trace element to bioaccumulate in organisms.

\section{Diatoms}

Diatoms are microscopic algae that occur in almost all aquatic environments. They have a siliceous shell, or frustule, consisting of two valves (halves), that is preserved in sediment. Because many diatom species are sensitive to changes in environmental conditions (for example, $\mathrm{pH}$, light, temperature, and concentrations of nutrients, trace elements, and pesticides), changes in diatom species composition and abundance can be used as indicators of environmental changes (Dixit and others, 1992; Stoermer and Smol, 1999). 
Diatoms are useful for assessing the trophic condition and trophic history of a lake. For example, a lake may be characterized as eutrophic (nutrient rich, high primary productivity) or oligotrophic (nutrient poor, low primary productivity) (Horne and Goldman, 1994). Several diatom species are indicators of eutrophic and oligotrophic conditions (Stoermer and Smol, 1999). Generally, in eutrophic water, the diatom community will be dominated by a few abundant species tolerant of nutrient and organic enrichment. In contrast, diatom communities in uncontaminated water (free of sewage or other organic enrichment caused by waste discharge) consist of a greater number of more equally abundant species (U.S. Environmental Protection Agency, 1977; John Smol, Queen's University, Kingston, Ontario, Canada, written commun., 2007).

\section{Sedimentation}

Based on the mean annual volume of water-storage capacity lost to sedimentation from 1948 to 1990, and extrapolating to 2006, the total volume of bottom sediment in the original conservation pool of Fall River Lake (as of 2006) was estimated to be about 470 million $\mathrm{ft}^{3}$ or about 10,800 acre-ft. The estimated sediment volume occupied about 36 percent of the original conservation-pool, water-storage capacity of the reservoir. Water-storage capacity in the conservation pool has been lost to sedimentation at a rate of less than 1 percent annually. Because most of the deposited sediment is contributed by large inflows, an indication of the year-to-year variability in sedimentation is provided by the year-to-year variability in streamflow. Variability in the mean annual flow at three locations within the Fall River Basin is shown in figure 3.

Mean annual net sediment yield, computed as the total volume of deposited sediment (10,800 acre-ft) divided by basin size $\left(554 \mathrm{mi}^{2}\right)$ and reservoir age (58 years), was estimated to be $0.34 \mathrm{acre}-\mathrm{ft} / \mathrm{mi}^{2} / \mathrm{yr}$. A comparison of the volumetric sediment yield with other selected reservoir basins in Kansas is provided in table 4. Among the reservoirs compared, the sediment yield for Fall River Lake was relatively low. In an analysis that included the other 11 reservoirs listed in table 4, a statistically significant positive correlation (significant at the 0.001 level) between sediment yield and mean annual precipitation (Spearman's rho $=0.86$ ) was indicated (Juracek, 2004). In the same analysis, no statistically significant correlation (at the 0.05 level) was indicated for the relation between sediment yield and mean soil permeability, mean slope, or land use. Within a given basin, sediment yield is a result of the complex interaction among several natural and human-related factors.

Table 4. Sediment yield, precipitation, and land use for selected reservoir basins in Kansas.

[Reservoir basins are ordered from largest to smallest in sediment yield. Information for reservoirs other than Fall River Lake from Juracek, 2004]

\begin{tabular}{|c|c|c|c|c|}
\hline \multirow[t]{2}{*}{ Reservoir basin } & \multirow{2}{*}{$\begin{array}{l}\text { Sediment yield (acre-feet per } \\
\text { square mile per year) }\end{array}$} & \multirow{2}{*}{$\begin{array}{l}\text { Mean annual pre- } \\
\text { cipitation (inches) }\end{array}$} & \multicolumn{2}{|c|}{ Land use } \\
\hline & & & $\begin{array}{l}\text { Cropland (per- } \\
\text { cent) }\end{array}$ & $\begin{array}{l}\text { Grassland } \\
\text { and woodland } \\
\text { (percent) }\end{array}$ \\
\hline \multicolumn{5}{|c|}{ Small reservoir basins } \\
\hline Mound City Lake & 2.03 & 40 & 16.3 & 79.5 \\
\hline Crystal Lake & 1.72 & 40 & 10.7 & 66.0 \\
\hline Mission Lake & 1.42 & 35 & 69.9 & 26.4 \\
\hline Gardner City Lake & .85 & 39 & 30.8 & 46.4 \\
\hline Otis Creek Reservoir & .71 & 33 & .1 & 96.5 \\
\hline Lake Afton & .66 & 30 & 81.0 & 15.2 \\
\hline \multicolumn{5}{|c|}{ Large reservoir basins } \\
\hline Perry Lake & 1.59 & 37 & 40.0 & 57.0 \\
\hline Hillsdale Lake & .97 & 41 & 35.4 & 57.3 \\
\hline Tuttle Creek Lake & .40 & 30 & 66.0 & 32.0 \\
\hline Fall River Lake & .34 & 38 & 4.0 & 93.0 \\
\hline Cheney Reservoir & .22 & 27 & 72.7 & 25.4 \\
\hline Webster Reservoir & .03 & 21 & 61.1 & 38.3 \\
\hline
\end{tabular}




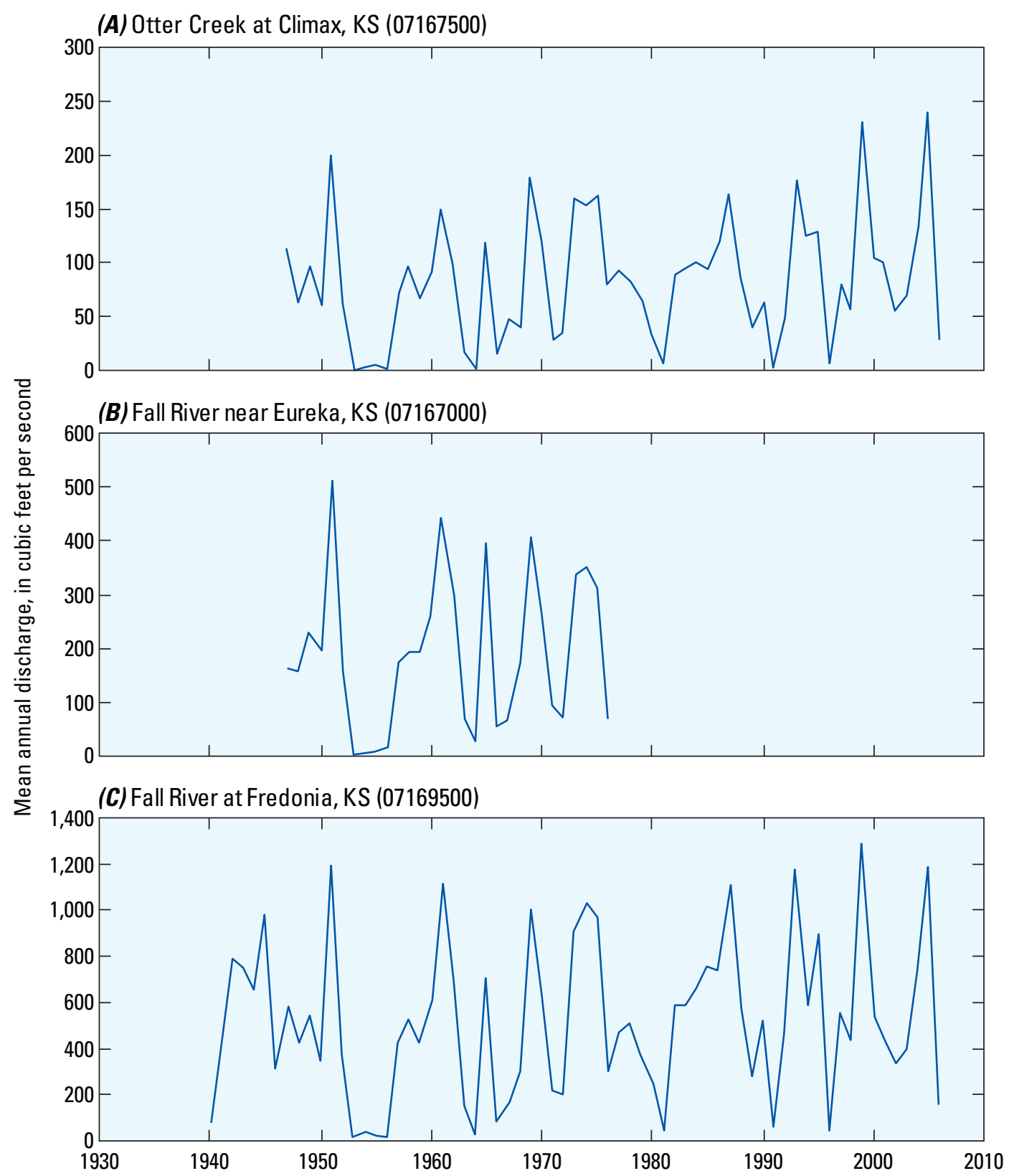

Figure 3. Variation in mean annual flow for Otter Creek at Climax, Fall River near Eureka, and Fall River at Fredonia, Kansas.

The total mass of bottom sediment, computed as the total volume of bottom sediment multiplied by the representative bulk density of the sediment $\left(40 \mathrm{lb} / \mathrm{ft}^{3}\right)$, was estimated to be 18.8 billion $\mathrm{lb}$. Mean annual net sediment deposition in the conservation pool of the reservoir, computed as the total bottom-sediment mass divided by reservoir age (58 yrs), was estimated to be 324 million lb/yr. Mean annual net sediment yield, computed as the mean annual net deposition divided by basin area $\left(554 \mathrm{mi}^{2}\right)$, was estimated to be $585,000\left(\mathrm{lb} / \mathrm{mi}^{2}\right) / \mathrm{yr}$. In comparison, Juracek (2004) used similar methods to estimate a mean annual net sediment yield of $964,000\left(\mathrm{lb} / \mathrm{mi}^{2}\right) / \mathrm{yr}$ for Otis Creek Reservoir (completed in 1971), which is located within the Fall River Lake Basin (fig. 1). Several factors may account for the difference in sediment yield including topog- raphy, land-management practices, sediment storage, and the time period analyzed (that is, 1948 to 2006 for Fall River Lake versus 1971 to 2002 for Otis Creek Reservoir). Moreover, the difference may be indicative of the variability of sediment yield throughout the Fall River Lake Basin and the fact that a small percentage of a basin can account for a large percentage of the sediment yield (Morris and Fan, 1998; Russell and others, 2001).

The particle-size composition of the bottom sediment sampled in Fall River Lake was uniform. At every site and sampling depth, the silt and (or) clay content of the sediment was greater than 99 percent (tables A3, A4, and A5 at the back of this report). 


\section{Occurrence of, and Trends in, Selected Chemical Constituents and Diatoms}

This section describes the occurrence of, and trends in, selected chemical constituents and diatoms in bottomsediment samples collected from Fall River Lake in southeast Kansas. Chemical analyses were performed using sediment samples from cores F-2B, F-4, and F-5 (fig. 2). Only the near-dam core $\mathrm{F}-2 \mathrm{~B}$ was analyzed for diatoms.

\section{Nutrients and Total Organic Carbon}

TN concentrations in the bottom sediment of Fall River Lake were remarkably uniform. For all sample intervals of cores $\mathrm{F}-2 \mathrm{~B}, \mathrm{~F}-4$, and $\mathrm{F}-5$, the TN concentration was 2,000 $\mathrm{mg} / \mathrm{kg}$ (tables A3, A4, and A5 at the back of this report). The mean annual net load of TN deposited in the bottom sediment of Fall River Lake, computed as the mean annual net sediment deposition multiplied by the representative $\mathrm{TN}$ concentration $(2,000 \mathrm{mg} / \mathrm{kg})$, was estimated to be $648,000 \mathrm{lb} / \mathrm{yr}$. The mean annual net yield of TN from the Fall River Lake Basin, computed as the mean annual net load divided by basin area, was estimated to be $1,170\left(\mathrm{lb} / \mathrm{mi}^{2}\right) / \mathrm{yr}$.

In comparison, the $\mathrm{TN}$ concentrations in a 5-interval sediment core collected from Otis Creek Reservoir (and analyzed using the same laboratory methods) essentially were uniform with a median of $2,300 \mathrm{mg} / \mathrm{kg}$. The estimated mean annual net yield of TN from the Otis Creek Reservoir Basin was 2,210 $\left(\mathrm{lb} / \mathrm{mi}^{2}\right) / \mathrm{yr}$ (Juracek, 2004).

TP concentrations for the sample intervals of Fall River Lake cores F-2B, F-4, and F-5 ranged from 730 to $910 \mathrm{mg} / \mathrm{kg}$ (tables A3, A4, and A5). The mean TP concentration for cores $\mathrm{F}-2 \mathrm{~B}, \mathrm{~F}-4$, and F-5 was 820,810 , and $740 \mathrm{mg} / \mathrm{kg}$, respectively. Computed using the sample intervals for all three Fall River Lake cores (that is, 18 intervals), the respective mean and median TP concentration was 810 and $820 \mathrm{mg} / \mathrm{kg}$. Using the median concentration, the mean annual net load and yield of TP was estimated to be $267,000 \mathrm{lb} / \mathrm{yr}$ and $480\left(\mathrm{lb} / \mathrm{mi}^{2}\right) / \mathrm{yr}$, respectively.

In comparison, the median TP concentration in a 5-interval core collected from Otis Creek Reservoir (and analyzed using the same laboratory methods) was $620 \mathrm{mg} / \mathrm{kg}$. The estimated mean annual net yield of TP from the Otis Creek Reservoir Basin was about 600 (lb/mi²)/yr (Juracek, 2004).

Nutrient concentrations in sediment, as well as estimated nutrient yields, vary substantially throughout the State. For example, in a study of bottom sediments collected from 10 small reservoirs in eastern Kansas (and analyzed using the same laboratory methods), median $\mathrm{TN}$ and TP concentrations ranged from 1,400 to $3,700 \mathrm{mg} / \mathrm{kg}$ and from 550 to 1,300 $\mathrm{mg} / \mathrm{kg}$, respectively. Mean annual net TN and TP yields, estimated for five of the small reservoirs, had respective ranges of 2,210 to $6,800\left(\mathrm{lb} / \mathrm{mi}^{2}\right) / \mathrm{yr}$ and 598 to $2,420\left(\mathrm{lb} / \mathrm{mi}^{2}\right) / \mathrm{yr}$

(Juracek, 2004). Statistical analysis, with a significance level of 0.05 , indicated no significant correlations between median
TN and TP concentrations in bottom sediment and land use. Likewise, a comparison of TN and TP yields with land use for the five small reservoirs for which nutrient yields were estimated also indicated no discernible relation (Juracek, 2004). The variability in nutrient concentrations in sediment may be caused, in part, by factors for which information is not readily available. Such information includes background nutrient contributions from soils and bedrock, historical land-management practices, historical application of fertilizers, historical livestock production, sediment sources, and in-reservoir processes.

For Fall River Lake core F-2B, a statistically significant positive trend in TP concentrations (TP concentration increased toward the top of the sediment core) was indicated (fig. 4, tables 5 and A3). Because the ${ }^{137} \mathrm{Cs}$ activity has a welldefined 1963-64 peak followed by a uniform, exponential decrease (fig. 5), it was concluded that the bottom sediment at coring site $\mathrm{F}-2 \mathrm{~B}$ is relatively undisturbed, and any trends may be considered meaningful. However, despite the statistical significance, the trend in TP concentration may not be representative of an actual trend because of analytical variance (defined here as the mean constituent concentration for the sediment core plus or minus 10 percent). This conclusion was based on the fact that most of the intervals in core $\mathrm{F}-2 \mathrm{~B}$ had a TP concentration that was within 10 percent of the mean TP concentration. No trend in TP concentrations was evident for the 5-interval core collected from Otis Creek Reservoir (Juracek, 2004).

TOC concentrations for the sample intervals of the three cores ranged from 1.5 to 1.8 percent (tables A3, A4, and A5) and were characterized by minimal variability within each core. A statistically significant trend in TOC concentrations was not indicated for core $\mathrm{F}-2 \mathrm{~B}$ (table 5).

\section{Trace Elements}

Generally, trace element concentrations in the bottom sediment of Fall River Lake were uniform over time (tables A3, A4, and A5). A statistically significant positive trend was indicated for cobalt, iron, manganese, and nickel concentrations in Fall River Lake core F-2B (table 5). However, because for each element all or most of the core intervals had concentrations that were within 10 percent of the mean concentration, the trends may be a result of analytical variance. Trace element concentrations in a 5-interval core collected from Otis Creek Reservoir (and analyzed using the same laboratory methods) generally were uniform over time, though typically smaller (Juracek, 2004).

Available SQGs allowed for the assessment of sediment quality with respect to eight trace elements. Silver was not detected in the bottom sediment of Fall River Lake. Cadmium, copper, and lead concentrations were less than the respective threshold-effects guidelines. All or most arsenic, chromium, nickel, and zinc concentrations were greater than the respective threshold-effects guidelines. No trace element concentrations exceeded the probable-effects guidelines (tables 3, A3, $\mathrm{A} 4$, and A5). 
Table 5. Results of trend tests on concentrations of selected constituents in bottom-sediment samples collected from Fall River Lake core F-2B, southeast Kansas, October 2006.

$[--$, not determined $]$

\section{Constituent}

Spearman's rho Trend test at 0.05 level of significance (two-sided p-value)

\begin{tabular}{|c|c|c|}
\hline \multicolumn{3}{|c|}{ Nutrients } \\
\hline Total nitrogen & 0 & no trend (--) \\
\hline Total phosphorus & 0.98 & positive trend $(0)$ \\
\hline \multicolumn{3}{|c|}{ Carbon } \\
\hline Carbon, total organic & .06 & no trend $(0.861)$ \\
\hline Carbon, total & -.34 & no trend $(0.287)$ \\
\hline \multicolumn{3}{|c|}{ Trace elements } \\
\hline Aluminum & .20 & no trend $(0.542)$ \\
\hline Antimony & .14 & no trend $(0.653)$ \\
\hline Arsenic & .53 & no trend $(0.077)$ \\
\hline Barium & -.47 & no trend $(0.120)$ \\
\hline Beryllium & .38 & no trend $(0.227)$ \\
\hline Cadmium & .27 & no trend $(0.397)$ \\
\hline Chromium & .49 & no trend $(0.104)$ \\
\hline Cobalt & .89 & positive trend $(0.0001)$ \\
\hline Copper & .43 & no trend $(0.160)$ \\
\hline Iron & .83 & positive trend $(0.0008)$ \\
\hline Lead & .08 & no trend $(0.809)$ \\
\hline Lithium & .34 & no trend $(0.285)$ \\
\hline Manganese & .66 & positive trend (0.019) \\
\hline Molybdenum & -- & -- \\
\hline Nickel & .61 & positive trend $(0.037)$ \\
\hline Selenium & -.05 & no trend $(0.874)$ \\
\hline Silver & -- & -- \\
\hline Strontium & -.57 & no trend $(0.053)$ \\
\hline Sulfur & .05 & no trend $(0.889)$ \\
\hline Tin & .42 & no trend $(0.176)$ \\
\hline Thallium & -- & -- \\
\hline Titanium & -.39 & no trend $(0.208)$ \\
\hline Uranium & -- & -- \\
\hline Vanadium & .39 & no trend $(0.206)$ \\
\hline Zinc & .32 & no trend $(0.312)$ \\
\hline
\end{tabular}




\section{Diatoms}

At site F-2 in Fall River Lake (fig. 2), 20 different diatom species were identified in core F-2B. For 5 of the 12 core intervals analyzed, no diatoms were detected. For the remaining seven intervals the number of diatom species identified ranged from 1 to 18 . Complete information on the occurrence and relative abundance of diatom species in each interval is provided in table A6 at the back of this report.

Abundant diatoms were identified only in the top (most recent) and bottom (oldest) intervals of the core. In the top interval the diatom Aulacoseira granulata was dominant with a relative abundance of 60.3 percent. This diatom is indicative of eutrophic conditions (Hall and Smol, 1999; Blais and others, 2000; Dixit and others, 2000). Other relatively abundant diatoms in the top interval included Aulacoseira ambigua
(16.8 percent) and Aulacoseira alpigena (16.0 percent) (table A6). Aulacoseira ambigua has been recognized as an indicator of either meso-eutrophic or eutrophic conditions (van Dam and others, 1994; Blais and others, 2000; Clerk and others, 2000). Both Aulacoseira granulata and Aulacoseira ambigua typically are found in high nutrient, low light waters (Kling, 1998). In contrast, Aulacoseira alpigena is indicative of oligotrophic conditions (van Dam and others, 1994). The dominance of Aulacoseira granulata in the top interval indicates that conditions at Fall River Lake during the past few years were frequently, if not typically, eutrophic. The presence of Aulacoseira alpigena indicates that conditions were less eutrophic at times. The remaining 15 species identified in the top interval had relative abundances of less than 2 percent (table A6).

Core F-2B at site F-2 (fig. 2)

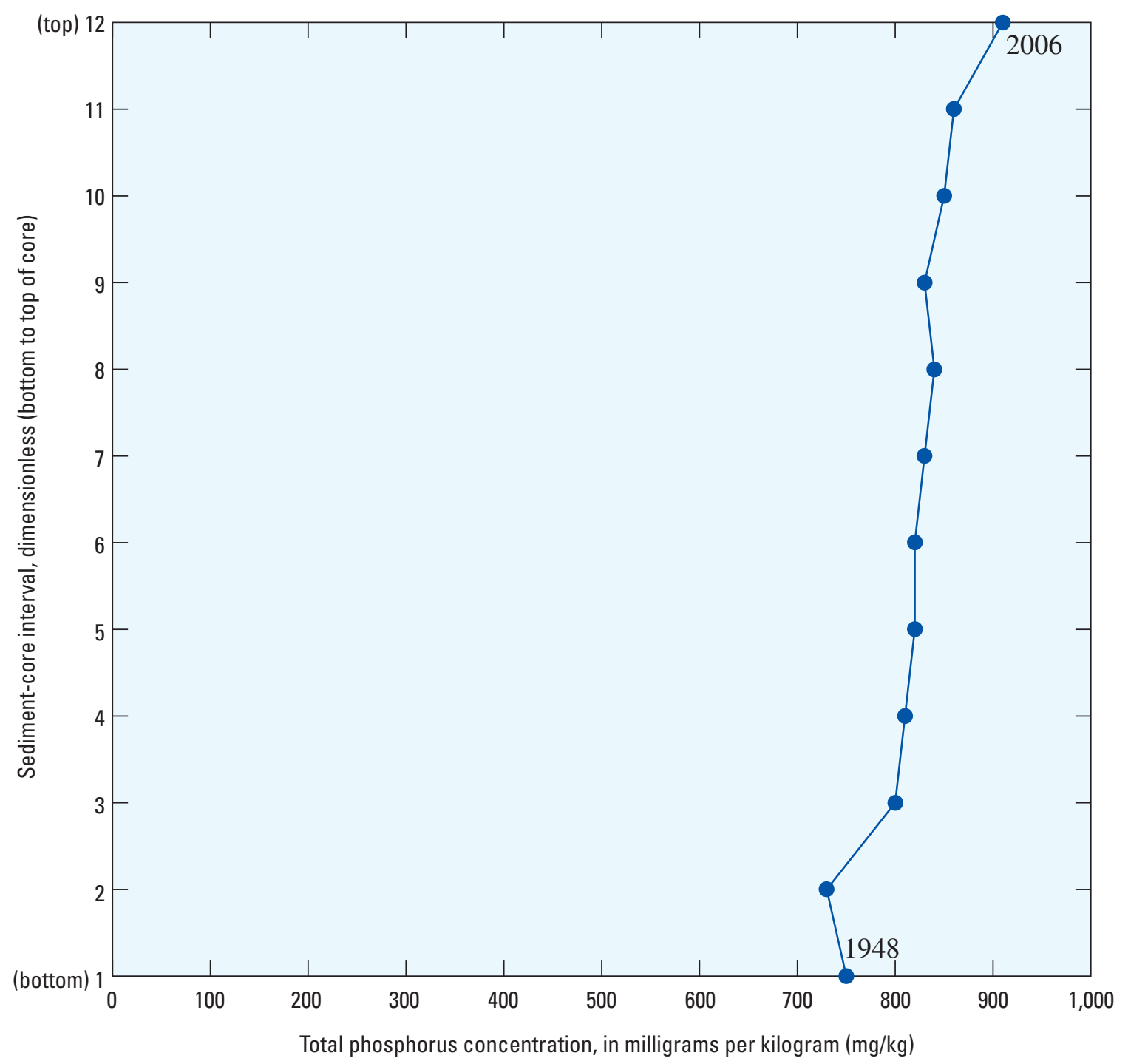

Figure 4. Variation in total phosphorus concentrations with depth of bottom-sediment samples collected from coring site F-2B in Fall River Lake, southeast Kansas, October 2006. 
In the bottom interval Aulacoseira granulata again was dominant with a relative abundance of 58.5 percent. Aulacoseira alpigena also was relatively abundant (27.5 percent) (table A6). Thus, similar to the recent past, it appears that conditions during the early history of Fall River Lake also were generally eutrophic with occasionally less eutrophic periods. The remaining 11 species identified in the bottom interval had relative abundances of less than 5 percent (table A6).

In the middle of the core, diatoms were sparse and five intervals contained no diatoms (table A6). Possible explanations to account for the absence of diatoms in the middle of the core include changes in $\mathrm{pH}$, light, temperature, and (or) concentrations of nutrients, trace elements, and pesticides; grazing pressure and (or) competition from other aquatic organisms; and lack of preservation in the sediment (Stoermer and Smol, 1999; Cohen, 2003). Because the concentrations of nutrients (total nitrogen and total phosphorus) and trace elements generally were uniform with depth in core F-2B (table A3), the absence of diatoms does not appear to be related to nutrient or trace element concentrations in the sediment. Comprehensive historical data on $\mathrm{pH}$, light, temperature, and pesticide concentrations were not available to assess changes over the entire life of the reservoir. However, as part of its Lake and Wetland Monitoring Program, KDHE sampled the water in Fall River Lake one day during the summer approximately every 3 years from 1975 to 2004. During that 30-year period, pH consistently ranged from 7.4 to 8.2. Pesticides, when analyzed, were not detected (Ed Carney, Kansas Department of Health and Environment, written commun., 2007).

Light limitation caused by turbidity in the water column is a possible explanation for the reduced abundance of diatoms in the middle of the sediment core (Bradbury and

Core F-2B at site F-2 (fig. 2)

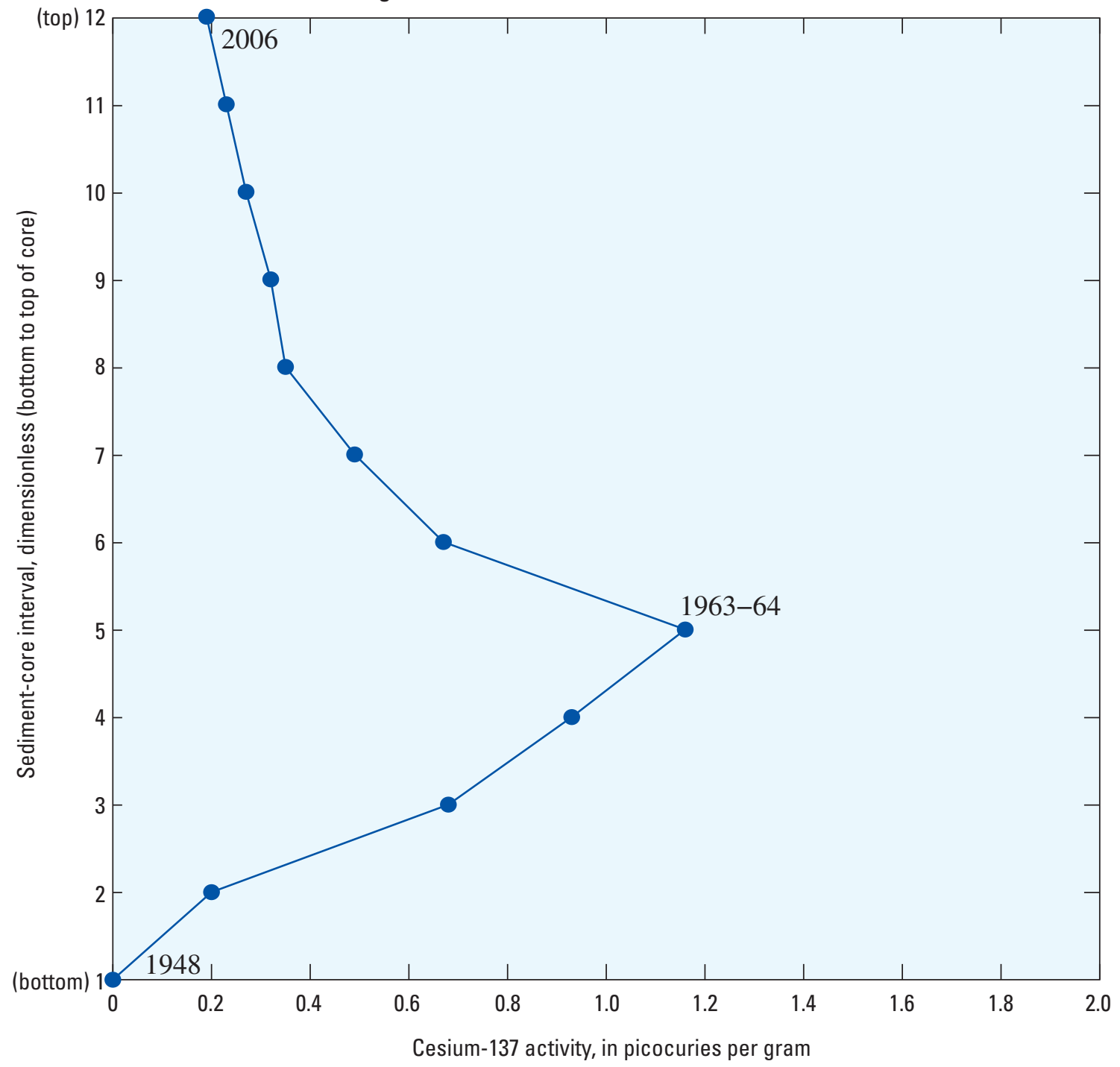

Figure 5. Variation in cesium-137 activity with depth of bottom-sediment samples collected from coring site F-2B in Fall River Lake, southeast Kansas, October 2006. 
Van Metre, 1997; Wetzel, 2001). Causes of turbidity include sediment delivered by reservoir inflows and wind-induced sediment resuspension. Fall River Lake has been characterized as typically turbid and the resulting light limitation is believed to limit primary production in the reservoir despite plentiful supplies of nitrogen and phosphorus in the water (U.S. Army Corps of Engineers, 1999). Measurements made by KDHE about once every 3 years from 1975 to 2004 indicated a range in turbidity of only 12 to 77 NTU (nephelometric turbidity units) (Ed Carney, Kansas Department of Health and Environment, written commun., 2007). Given the sampling frequency, the representativeness of the turbidity data is uncertain.

Because diatoms generally are ubiquitous in the environment, it seems unlikely that they would be completely absent in the reservoir for years at a time. Thus, another possibility that could account for the absence of diatoms in the sediment is that the diatoms were present in the reservoir but not preserved. In other words, the diatoms may have disappeared because of dissolution in the water column and (or) postdepositionally in the sediment (Battarbee and others, 2001; Cohen, 2003). Pronounced evidence of postdepositional dissolution (for example, diatom valves with corroded edges) was not observed in the sediment samples analyzed (Yangdong Pan, Portland State University, written commun., 2007). Kling (1998), however, stated that a core consisting of alternating intervals of relative abundance and absence of diatoms was evidence in support of dissolution.

To further investigate historical conditions given the absence of diatoms in the middle of the core, the top interval (relatively abundant diatoms), a middle interval (no diatoms), and the bottom interval (relatively abundant diatoms) were analyzed for the presence of cyanobacteria (blue-green algae). In all three intervals, similar abundances of the cyanobacteria Anabaena were detected (Ann St. Amand, PhycoTech, written commun., 2007). The abundance of Anabaena in the top, middle, and bottom intervals was about 14,200, 13,400, and 13,600 per gram of sediment, respectively. Anabaena, and cyanobacteria in general, are indicative of eutrophic conditions (Wetzel, 2001). Thus, the presence of Anabaena in all three intervals provides evidence for the existence of eutrophic conditions during the early, middle, and recent history of the reservoir. Given the abundance of Anabaena, and the presence of other cyanobacteria, it is likely that algal blooms occur in the reservoir that may result in taste-and-odor compounds and possibly algal toxins.

Chlorophyll-a is used as a surrogate indicator of eutrophication (Wetzel, 2001; Wehr and Sheath, 2003). From 1975 to 2004, measurements made by KDHE about once every 3 years indicated that chlorophyll-a concentrations in the water ranged from about 4 to 36 parts per billion (ppb) and typically were less than $13 \mathrm{ppb}$. KDHE classifies the trophic condition of a lake using the following chlorophyll-a criteria: oligotrophic (0 to $2.4 \mathrm{ppb}$ ), mesotrophic (2.4 to $7.2 \mathrm{ppb}$ ), slightly eutrophic (7.2 to $12 \mathrm{ppb}$ ), eutrophic (12 to $20 \mathrm{ppb}$ ), very eutrophic (20 to $30 \mathrm{ppb}$ ), and hypereutrophic (greater than $30 \mathrm{ppb)} \mathrm{(Ed} \mathrm{Carney,}$ Kansas Department of Health and Environment, written com- mun., 2007). Based on these criteria, Fall River Lake generally varied from mesotrophic to eutrophic from 1975 to 2004. Fall River Lake also was classified as eutrophic based on the total phosphorus content in the water (U.S. Army Corps of Engineers, 1999; Wetzel, 2001). From 1981 to 2004, measurements made by KDHE about once every 3 years indicated that total phosphorus concentrations in the water ranged from 0.04 to 0.15 milligrams per liter (Ed Carney, Kansas Department of Health and Environment, written commun., 2007). Together, the diatom and cyanobacteria evidence, combined with the available water-quality data, indicated that Fall River Lake likely has been eutrophic throughout much of its history.

\section{Summary and Conclusions}

A 2-year study by the U.S. Geological Survey, in cooperation with the Kansas Department of Health and Environment, was begun in 2006 to investigate sedimentation in, and the occurrence of selected chemical constituents and diatoms in bottom sediment of, Fall River Lake, southeast Kansas, for 1948 through 2006. The study used a combination of available bathymetric-survey information and bottom-sediment coring completed in 2006. The major results of this study are listed below:

1. The total estimated volume and mass of bottom sediment in the original conservation pool of Fall River Lake was 470 million $\mathrm{ft}^{3}$ and 18.8 billion $\mathrm{lb}$, respectively.

2. The estimated sediment volume occupied about 36 percent of the original conservation-pool, water-storage capacity of Fall River Lake.

3. Mean annual net sediment deposition in the original conservation pool of Fall River Lake was estimated to be 324 million lb/yr.

4. Mean annual net sediment yield from the Fall River Lake Basin was estimated to be $585,000\left(\mathrm{lb} / \mathrm{mi}^{2}\right) / \mathrm{yr}$.

5. Total nitrogen in the bottom sediment of Fall River Lake was uniform over time with a concentration of $2,000 \mathrm{mg} / \mathrm{kg}$.

6. The mean annual net load and yield of total nitrogen deposited in the bottom sediment of Fall River Lake was estimated to be $648,000 \mathrm{lb} / \mathrm{yr}$ and $1,170\left(\mathrm{lb} / \mathrm{mi}^{2}\right) / \mathrm{yr}$, respectively.

7. Total phosphorus in the bottom sediment of Fall River Lake generally was uniform over time with a median concentration of $820 \mathrm{mg} / \mathrm{kg}$.

8. The mean annual net load and yield of total phosphorus deposited in the bottom sediment of Fall River Lake was estimated to be 267,000 lb/yr and 480 $\left(\mathrm{lb} / \mathrm{mi}^{2}\right) / \mathrm{yr}$, respectively. 
9. Trace element concentrations in the bottom sediment of Fall River Lake generally were uniform over time.

10. Arsenic, chromium, nickel, and zinc concentrations in the bottom sediment of Fall River Lake typically exceeded the threshold-effects guidelines, which represent the concentrations above which toxic biological effects occasionally occur.

11. Trace element concentrations did not exceed the probableeffects guidelines (available for eight trace elements), which represent the concentrations above which toxic biological effects usually or frequently occur.

12. Occurrence of the diatom Aulacoseira granulata and the cyanobacteria Anabaena in the bottom sediment of Fall River Lake, combined with historical water-quality data, indicated that Fall River Lake likely has been eutrophic throughout much of its history.

13. Diatoms were absent in the middle part of a Fall River Lake sediment core possibly as a result of lack of preservation caused by dissolution.

\section{References Cited}

Acker, F., Russell, B., and Hagan, E., 2002, Diatom cleaning by nitric acid digestion with a microwave apparatus, Protocol P-13-42, in Charles, D. F., Knowles, C., and Davis, R.S., eds., Protocols for the analysis of algal samples collected as part of the U.S. Geological Survey National Water-Quality Assessment Program: Report No. 02-06, Patrick Center for Environmental Research, The Academy of Natural Sciences, Philadelphia, Pennsylvania, 124 p. Available on the Web at http://diatom.acnatsci.org/nawqa/

Adriano, D.C., 1986, Trace elements in the terrestrial environment: New York, Springer-Verlag, 533 p.

Arbogast, B.F., 1996, Analytical methods manual for the Mineral Resource Surveys Program: U.S. Geological Survey Open-File Report 96-525, 248 p.

Battarbee, R.W., Jones, V.J., Flower, R.J., Cameron, N.G., Bennion, Helen, Carvalho, Laurence, and Juggins, Stephen, 2001, Diatoms, in Smol, J.P., Birks, H.J.B., and Last, W.M., eds., Tracking environmental change using lake sediments, volume 3-terrestrial, algal, and siliceous indicators: Boston, Kluwer Academic Publishers, 371 p.

Baudo, Renato, Giesy, J.P., and Muntau, Herbert, eds., 1990, Sediments - chemistry and toxicity of in-place pollutants: Ann Arbor, Michigan, Lewis Publishers, 405 p.
Blais, J.M., Duff, K.E., Schindler, D.W., Smol, J.P., Leavitt, P.R., and Agbeti, Michael, 2000, Recent eutrophication histories in Lac Ste. Anne and Lake Isle, Alberta, Canada, inferred using paleolimnological methods: Lake and Reservoir Management, v. 16, p. 292-304.

Blomqvist, Sven, 1985, Reliability of core sampling of soft bottom sediment - an in situ study: Sedimentology, v. 32, p. 605-612.

Blomqvist, Sven, and Bostrom, Kurt, 1987, Improved sampling of soft bottom sediments by combined box and piston coring: Sedimentology, v. 34, p. 715-719.

Bradbury, J.P., and Van Metre, P.C., 1997, A land-use and water-quality history of White Rock Lake reservoir, Dallas, Texas, based on paleolimnological analyses: Journal of Paleolimnology, v. 17, p. 227-237.

Briggs, P.H., and Meier, A.L., 1999, The determination of forty two elements in geological materials by inductively coupled plasma-mass spectrometry: U.S. Geological Survey Open-File Report 99-166, 15 p.

Brune, G.M., 1953, Trap efficiency of reservoirs: Transactions of the American Geophysical Union, v. 34, p. 407-448.

Charles, M.J., and Hites, R.A., 1987, Sediments as archives of environmental pollution trends, chap. 12, in Hites, R.A., and Eisenreich, S.J., eds., Sources and fates of aquatic pollutants: Washington, D.C., American Chemical Society, Advances in Chemistry Series 216, p. 365-389.

Clerk, S., Hall, R., Quinlan, R., and Smol, J.P., 2000, Quantitative inferences of past hypolimnetic anoxia and nutrient levels from a Canadian Precambrian Shield lake: Journal of Paleolimnology, v. 23, p. 319-336.

Cohen, A.S., 2003, Paleolimnology — the history and evolution of lake systems: New York, Oxford University Press, 500 p.

Cole, G.A., 1994, Textbook of limnology (4th ed.): Prospect Heights, Illinois, Waveland Press, Inc., 412 p.

Davies, B.E., 1983, Heavy metal contamination from base metal mining and smelting -implications for man and his environment, chap. 14, in Thornton, Iain, ed., Applied environmental geochemistry: New York, Academic Press, 501 p.

Dixit, A.S., Hall, R.I., Leavitt, P.R., Quinlan, R., and Smol, J.P., 2000, Effects of sequential depositional basins on lake response to urban and agricultural pollution-A palaeoecological analysis of the Qu' Appelle Valley, Saskatchewan, Canada: Freshwater Biology, v. 43, p. 319-337.

Dixit, S.S., Smol, J.P., Kingston, J.C., and Charles, D.F., 1992, Diatoms - powerful indicators of environmental change: Environmental Science and Technology, v. 26, no. 1, p. 23-33. 
Emery, K.O., and Hulsemann, J., 1964, Shortening of sediment cores collected in open barrel gravity corers: Sedimentology, v. 3, p. 144-154.

Fenneman, N.M., 1946, Physical divisions of the United States: U.S. Geological Survey special map, scale $1: 7,000,000,1$ sheet.

Fishman, M.J., and Friedman, L.C., eds., 1989, Methods for determination of inorganic substances in water and fluvial sediments: U.S. Geological Survey Techniques of WaterResources Investigations, book 5, chap. A1, 545 p.

Forstner, Ulrich, and Wittmann, G.T.W., 1981, Metal pollution in the aquatic environment: New York, Springer-Verlag, $486 \mathrm{p}$.

Gordon, N.D., McMahon, T.A., and Finlayson, B.L., 1992, Stream hydrology—an introduction for ecologists: New York, John Wiley \& Sons, 526 p.

Grosbois, C., Horowitz, A.J., Smith, J.J., and Elrick, K.A., 2001, The effect of mining and related activities on the sediment-trace element geochemistry of Lake Coeur d'Alene, Idaho, USA, part III, Downstream effects- the Spokane River Basin: Hydrological Processes, v. 15, p. 855-875.

Guy, H.P., 1969, Laboratory theory and methods for sediment analysis: U.S. Geological Survey Techniques of WaterResources Investigations, book 5, chap. C1, 58 p.

Hakanson, L., and Jansson, M., 1983, Principles of lake sedimentology: New York, Springer-Verlag, 316 p.

Hall, R.I., and Smol, J.P., 1999, Diatoms as indicators of lake eutrophication, chap. 6, in Stoermer, E.F., and Smol, J.P., eds., The diatoms-Applications for the environmental and earth sciences: New York, Cambridge University Press, p. $128-168$.

Helsel, D.R., and Hirsch, R.M., 1992, Statistical methods in water resources: Amsterdam, Elsevier Science Publishers, $529 \mathrm{p}$.

Hem, J.D., 1989, Study and interpretation of the chemical characteristics of natural water ( $3 \mathrm{~d}$ ed.): U.S. Geological Survey Water-Supply Paper 2254, 263 p.

High Plains Regional Climate Center, 2007, Historical data summaries: Information available on the Web, accessed January 24, 2007, at http://www.hprcc.unl.edu/

Holmes, C.W., Robbins, J., Halley, R., Bothner, M., Ten Brink, M., and Marot, M., 2001, Sediment dynamics of Florida Bay mud banks on a decadal time scale: Bulletins of American Paleontology, no. 361, p. 31-40.

Hongve, Dag, and Erlandsen, A.H., 1979, Shortening of surface sediment cores during sampling: Hydrobiologia, v. 65, no. 3, p. 283-287.
Horne, A.J., and Goldman, C.R., 1994, Limnology (2d ed.): New York, McGraw-Hill, Inc., 576 p.

Horowitz, A.J., 1991, A primer on sediment-trace element chemistry (2nd ed.): Chelsea, Michigan, Lewis Publ., 136 p.

Horowitz, A.J., Elrick, K.A., and Smith, J.J., 2001, Estimating suspended sediment and trace element fluxes in large river basins-methodological considerations as applied to the NASQAN program: Hydrological Processes, v. 15, p. 1107-1132.

Juracek, K.E., 2004, Sedimentation and occurrence and trends of selected chemical constituents in bottom sediment of 10 small reservoirs, eastern Kansas: U.S. Geological Survey Scientific Investigations Report 2004-5228, 80 p.

Kansas Applied Remote Sensing Program, 1993, Kansas land cover data base, scale 1:100,000: Information available on the Web, accessed October 20, 2006, at $h t t p: / / w w w$.

KansasGIS.org

Kansas Department of Health and Environment, 2007, Kansas water-quality impaired water bodies (303(d) list): Information available on the Web, accessed January 23, 2007, at http://www.kdheks.gov/tmdl/methodology.htm

Karickhoff, S.W., 1984, Organic pollutant sorption in aquatic systems: Journal of Hydraulic Engineering, v. 110, no. 6, p. 707-735.

Kling, H.J., 1998, A summary of past and recent plankton of Lake Winnipeg, Canada using algal fossil remains: Journal of Paleolimnology, v. 19, p. 297-307.

Krammer, K., and Lange-Bertalot, H., 1986, Bacillariophyceae, 1. Teil—Naviculaceae: Jena, Germany, VEB Gustav Fisher Verlag, 876 p.

Krammer, K., and Lange-Bertalot, H., 1988, Bacillariophyceae, 2. Teil—Epithemiaceae, bacillariaceae, surirellaceae: Jena, Germany, VEB Gustav Fisher Verlag, 596 p.

Krammer, K., and Lange-Bertalot, H., 1991a, Bacillariophyceae, 3. Teil-Centrales, fragilariaceae, eunotiaceae, achnanthaceae: Jena, Germany, VEB Gustav Fisher Verlag, $576 \mathrm{p}$.

Krammer, K., and Lange-Bertalot, H., 1991b, Bacillariophyceae. 1. Teil—Achnanthaceae, kritische erganzungen zu navicula (lineolatae) und gomphonema: Jena, Germany, VEB Gustav Fisher Verlag, 437 p.

Lide, D.R., ed., 1993, CRC handbook of chemistry and physics (74th ed.): Boca Raton, Florida, CRC Press, various pagination. 
MacDonald, D.D., Ingersoll, C.G., and Berger, T.A., 2000, Development and evaluation of consensus-based sediment quality guidelines for freshwater ecosystems: Archives of Environmental Contamination and Toxicology, v. 39, p. 20-31.

Morris, G.L., and Fan, Jiahua, 1998, Reservoir sedimentation handbook: New York, McGraw-Hill, various pagination.

Pais, Istvan, and Jones, J.B., Jr., 1997, The handbook of trace elements: Boca Raton, Florida, St. Lucie Press, 223 p.

Patrick, R., and Reimer, C.W., 1966, The diatoms of the United States, volume 1: Monographs of the Academy of Natural Sciences of Philadelphia, no.13, 688 p.

Patrick, R., and Reimer, C.W., 1975, The diatoms of the United States, volume 2, part 1: Monographs of the Academy of Natural Sciences of Philadelphia, no.13, 213 p.

Ritchie, J.C., and McHenry, J.R., 1990, Application of radioactive fallout cesium-137 for measuring soil erosion and sediment accumulation rates and patterns-a review: Journal of Environmental Quality, v. 19, p. 215-233.

Russell, M.A., Walling, D.E., and Hodgkinson, R.A., 2001, Suspended sediment sources in two small lowland agricultural catchments in the UK: Journal of Hydrology, v. 252, p. 1-24.

Schoewe, W.H., 1949, The geography of Kansas: Transactions Kansas Academy of Science, v. 52, p. 261-333.

Smol, J.P., 2002, Pollution of lakes and rivers-a paleoenvironmental perspective: New York, Oxford University Press, $280 \mathrm{p}$.

Stoermer, E.F., and Smol, J.P., eds., 1999, The diatomsapplications for the environmental and earth sciences: New York, Cambridge University Press, 469 p.

U.S. Army Corps of Engineers, 1999, Water quality report, Fall River Lake, Kansas, 1998: Tulsa, Oklahoma, U.S. Army Corps of Engineers, Tulsa District, October 1999, 21 p., 4 appendices.

U.S. Department of Agriculture, Soil Conservation Service, 1982, Soil Survey of Greenwood County, Kansas: U.S. Department of Agriculture, Soil Conservation Service, $116 \mathrm{p}$.

U.S. Environmental Protection Agency, 1977, Algae and water pollution: Municipal Environmental Research Laboratory, Office of Research and Development, Report 600-77-036, $122 \mathrm{p}$.

U.S. Environmental Protection Agency, 1991, Guidance of water quality-based decisions - the TMDL process: Washington, D.C., Office of Water, EPA440/4-91-001, 59 p.
U.S. Environmental Protection Agency, 1997, The incidence and severity of sediment contamination in surface waters of the United States, volume 1-national sediment quality survey: U.S. Environmental Protection Agency Report 823-R-97-006, September 1997, various pagination.

van Dam, H., Mertens, A., and Sinkeldam, J., 1994, A coded checklist and ecological indicator values of freshwater diatoms from The Netherlands: Netherlands Journal of Aquatic Ecology, v. 28, no. 1, p. 117-133.

Van Metre, P.C., and Callender, Edward, 1996, Identifying water-quality trends in the Trinity River, Texas, USA, 1969-1992, using sediment cores from Lake Livingston: Environmental Geology, v. 28, no. 4, p. 190-200.

Van Metre, P.C., Callender, Edward, and Fuller, C.C., 1997, Historical trends in organochlorine compounds in river basins identified using sediment cores from reservoirs: Environmental Science \& Technology, v. 31, no. 8, p. 2339-2344.

Van Metre, P.C., and Mahler, B.J., 2004, Contaminant trends in reservoir sediment cores as records of influent stream quality: Environmental Science \& Technology, v. 38, p. 2978-2986.

Vanoni, V.A., ed., 2006, Sedimentation engineering: Reston, Virginia, American Society of Civil Engineers, 418 p.

Wehr, J.D., and Sheath, R.G., eds., 2003, Freshwater algae of North America—ecology and classification: New York, Academic Press, 918 p.

Wetzel, R.G., 2001, Limnology_lake and river ecosystems (3d ed.): New York, Academic Press, 1006 p.

Wise, S.M., 1980, Caesium-137 and lead-210 - a review of the techniques and some applications in geomorphology, chap. 9, in Cullingford, R.A., Davidson, D.A., and Lewin, J., eds., Timescales in geomorphology: New York, John Wiley \& Sons, $360 \mathrm{p}$.

Zoumis, Theofanis, Schmidt, Astrid, Grigorova, Lidia, and Calmano, Wolfgang, 2001, Contaminants in sediments-remobilisation and demobilisation: The Science of the Total Environment, v. 266, p. 195-202. 

Supplemental Information 
Table A1. Latitude and longitude coordinates, water depth, estimated sediment thickness, length of recovered core, and estimated recovery percentage for bottom-sediment coring sites at Fall River Lake, southeast Kansas.

\begin{tabular}{cccccccc}
\hline $\begin{array}{c}\text { Coring site num- } \\
\text { ber (fig. 2) }\end{array}$ & $\begin{array}{c}\text { Date cored } \\
\text { (month/day/ } \\
\text { year) }\end{array}$ & $\begin{array}{c}\text { Latitude } \\
\text { (decimal } \\
\text { degrees) }\end{array}$ & $\begin{array}{c}\text { Longitude } \\
\text { (decimal } \\
\text { degrees) }\end{array}$ & $\begin{array}{c}\text { Water } \\
\text { depth } \\
\text { (feet) }\end{array}$ & $\begin{array}{c}\text { Estimated } \\
\text { penetration } \\
\text { depth (feet) }\end{array}$ & $\begin{array}{c}\text { Length of recov- } \\
\text { ered core (feet) }\end{array}$ & $\begin{array}{c}\text { Estimated recov- } \\
\text { ery percentage }\end{array}$ \\
\hline F-2A & $10 / 24 / 06$ & 37.65408 & 96.06714 & 20.5 & -- & 7.4 & 6.6 \\
F-2B & $10 / 24 / 06$ & 37.65422 & 96.06717 & 20.5 & 10.0 & -- & 66 \\
F-4 & $10 / 24 / 06$ & 37.66775 & 96.08036 & 20.5 & -- & -1 & - \\
F-5 & $10 / 24 / 06$ & 37.66386 & 96.09533 & 9.0 & -- & 6.6 & - \\
\hline
\end{tabular}

${ }^{1}$ Recovery percentage could not be estimated for cores that did not penetrate to the original (pre-reservoir) land-surface material.

Table A2. Estimated bulk density of bottom sediment at coring sites in Fall River Lake, southeast Kansas.

[lb/ft ${ }^{3}$, pounds per cubic foot; --, not applicable]

\begin{tabular}{|c|c|c|c|}
\hline $\begin{array}{l}\text { Coring site num- } \\
\text { ber (fig. } 2 \text { ) }\end{array}$ & $\begin{array}{l}\text { Depth interval } \\
\text { (inches) }\end{array}$ & $\begin{array}{l}\text { Estimated bulk } \\
\text { density }\left(\mathrm{lb} / \mathrm{ft}^{3}\right)\end{array}$ & $\begin{array}{c}\text { Computed mean } \\
\text { bulk density } \\
\left({\left.\mathrm{Ib} / \mathrm{ft}^{3}\right)}^{3}\right.\end{array}$ \\
\hline \multirow[t]{8}{*}{$\mathrm{F}-2 \mathrm{~A}$} & $0-12.3$ & 26.9 & -- \\
\hline & $12.3-24.6$ & 28.3 & -- \\
\hline & $24.6-36.9$ & 32.2 & -- \\
\hline & $36.9-49.2$ & 34.1 & -- \\
\hline & $49.2-61.5$ & 33.7 & -- \\
\hline & $61.5-73.8$ & 38.4 & -- \\
\hline & $73.8-86.0$ & 38.7 & -- \\
\hline & & & 33.2 \\
\hline \multirow[t]{8}{*}{$\mathrm{F}-4$} & $0-12$ & 30.9 & -- \\
\hline & $12-24$ & 35.8 & -- \\
\hline & $24-36$ & 35.1 & -- \\
\hline & $36-48$ & 39.1 & -- \\
\hline & $48-60$ & 42.0 & -- \\
\hline & $60-72$ & 47.1 & -- \\
\hline & $72-84$ & 43.5 & -- \\
\hline & & & 39.1 \\
\hline \multirow[t]{7}{*}{$\mathrm{F}-5$} & $0-12.3$ & 44.4 & -- \\
\hline & $12.3-24.6$ & 43.4 & -- \\
\hline & $24.6-36.9$ & 44.0 & -- \\
\hline & $36.9-49.2$ & 47.8 & -- \\
\hline & $49.2-61.5$ & 53.8 & -- \\
\hline & $61.5-74.0$ & 53.6 & -- \\
\hline & & & 47.8 \\
\hline
\end{tabular}

${ }^{1}$ Mean bulk density computed as the average of the bulk densities for the individual depth intervals for each core. 
Table A3. Percentage of silt and clay and constituent concentrations for bottom-sediment samples collected from core F-2B at coring site F-2 (fig. 2) in Fall River Lake, southeast Kansas, October 2006.

[Shading indicates concentration greater than threshold-effects guideline listed in table 3. >, greater than; $\mathrm{mg} / \mathrm{kg}$, milligrams per kilogram; \%, percent dry weight; <, less than]

\begin{tabular}{|c|c|c|c|c|}
\hline \multirow{2}{*}{$\begin{array}{l}\text { Constituent and unit of } \\
\text { measurement }\end{array}$} & \multicolumn{4}{|c|}{ Constituent concentration } \\
\hline & $\begin{array}{c}\text { Interval } 1 \text { (bottom of } \\
\text { core) }\end{array}$ & Interval 2 & Interval 3 & Interval 4 \\
\hline Percentage of silt and clay & $>99$ & $>99$ & $>99$ & $>99$ \\
\hline \multicolumn{5}{|c|}{ Nutrients } \\
\hline Total nitrogen, $\mathrm{mg} / \mathrm{kg}$ & 2,000 & 2,000 & 2,000 & 2,000 \\
\hline Total phosphorus, $\mathrm{mg} / \mathrm{kg}$ & 750 & 730 & 800 & 810 \\
\hline \multicolumn{5}{|c|}{ Carbon } \\
\hline Carbon (total organic), $\%$ & 1.8 & 1.7 & 1.7 & 1.6 \\
\hline Carbon (total), $\%$ & 2.3 & 2.3 & 2.3 & 2.3 \\
\hline \multicolumn{5}{|c|}{ Trace elements } \\
\hline Aluminum, $\%$ & 9.6 & 9.1 & 10.0 & 9.9 \\
\hline Antimony, mg/kg & .7 & .8 & .7 & .7 \\
\hline Arsenic, mg/kg & 12 & 12 & 13 & 13 \\
\hline Barium, mg/kg & 620 & 620 & 610 & 610 \\
\hline Beryllium, mg/kg & 2.9 & 2.8 & 3.0 & 3.0 \\
\hline Cadmium, mg/kg & .4 & .5 & .5 & .4 \\
\hline Chromium, mg/kg & 99 & 95 & 100 & 100 \\
\hline Cobalt, mg/kg & 16 & 16 & 17 & 17 \\
\hline Copper, mg/kg & 25 & 24 & 26 & 25 \\
\hline Iron, $\%$ & 4.6 & 4.3 & 4.9 & 4.9 \\
\hline Lead, mg/kg & 29 & 28 & 31 & 30 \\
\hline Lithium, mg/kg & 69 & 65 & 74 & 72 \\
\hline Manganese, $\mathrm{mg} / \mathrm{kg}$ & 920 & 860 & 890 & 1,100 \\
\hline Molybdenum, mg/kg & $<1$ & $<1$ & $<1$ & $<1$ \\
\hline Nickel, mg/kg & 42 & 40 & 44 & 44 \\
\hline Selenium, mg/kg & .7 & .7 & .7 & .6 \\
\hline Silver, mg/kg & $<.5$ & $<.5$ & $<.5$ & $<.5$ \\
\hline Strontium, mg/kg & 190 & 190 & 190 & 200 \\
\hline Sulfur, $\%$ & .08 & .09 & .06 & .06 \\
\hline Thallium, mg/kg & $<50$ & $<50$ & $<50$ & $<50$ \\
\hline Tin, mg/kg & 4 & 3 & 4 & 4 \\
\hline Titanium, $\%$ & .48 & .50 & .48 & .48 \\
\hline Uranium, $\mathrm{mg} / \mathrm{kg}$ & $<50$ & $<50$ & $<50$ & $<50$ \\
\hline Vanadium, mg/kg & 130 & 120 & 130 & 130 \\
\hline Zinc, $\mathrm{mg} / \mathrm{kg}$ & 130 & 120 & 130 & 130 \\
\hline
\end{tabular}


Table A3. Percentage of silt and clay and constituent concentrations for bottom-sediment samples collected from core F-2B at coring site F-2 (fig. 2) in Fall River Lake, southeast Kansas, October 2006. - Continued

[Shading indicates concentration greater than threshold-effects guideline listed in table 3. >, greater than; $\mathrm{mg} / \mathrm{kg}$, milligrams per kilogram; \%, percent dry weight; $<$, less than]

\begin{tabular}{|c|c|c|c|c|}
\hline \multirow{2}{*}{$\begin{array}{c}\text { Constituent and unit of } \\
\text { measurement }\end{array}$} & \multicolumn{4}{|c|}{ Constituent concentration } \\
\hline & Interval 5 & Interval 6 & Interval 7 & Interval 8 \\
\hline Percentage of silt and clay & $>99$ & $>99$ & $>99$ & $>99$ \\
\hline \multicolumn{5}{|c|}{ Nutrients } \\
\hline Total nitrogen, $\mathrm{mg} / \mathrm{kg}$ & 2,000 & 2,000 & 2,000 & 2,000 \\
\hline Total phosphorus, mg/kg & 820 & 820 & 830 & 840 \\
\hline \multicolumn{5}{|c|}{ Carbon } \\
\hline Carbon (total organic), $\%$ & 1.6 & 1.6 & 1.6 & 1.7 \\
\hline Carbon (total), $\%$ & 2.3 & 2.1 & 2.2 & 2.2 \\
\hline \multicolumn{5}{|c|}{ Trace elements } \\
\hline Aluminum, $\%$ & 10.0 & 9.9 & 10.0 & 9.9 \\
\hline Antimony, mg/kg & .8 & .7 & .8 & .8 \\
\hline Arsenic, mg/kg & 13 & 13 & 14 & 13 \\
\hline Barium, mg/kg & 610 & 610 & 610 & 620 \\
\hline Beryllium, mg/kg & 3.1 & 3.1 & 3.1 & 3.0 \\
\hline Cadmium, mg/kg & .4 & .4 & .4 & .4 \\
\hline Chromium, mg/kg & 100 & 100 & 100 & 99 \\
\hline Cobalt, $\mathrm{mg} / \mathrm{kg}$ & 17 & 17 & 17 & 17 \\
\hline Copper, mg/kg & 26 & 26 & 26 & 27 \\
\hline Iron, $\%$ & 5.0 & 5.0 & 5.0 & 5.0 \\
\hline Lead, $\mathrm{mg} / \mathrm{kg}$ & 31 & 32 & 33 & 32 \\
\hline Lithium, $\mathrm{mg} / \mathrm{kg}$ & 73 & 73 & 74 & 73 \\
\hline Manganese, $\mathrm{mg} / \mathrm{kg}$ & 970 & 1,000 & 1,100 & 1,100 \\
\hline Molybdenum, mg/kg & $<1$ & $<1$ & $<1$ & $<1$ \\
\hline Nickel, mg/kg & 45 & 45 & 45 & 44 \\
\hline Selenium, $\mathrm{mg} / \mathrm{kg}$ & .6 & .6 & .7 & .7 \\
\hline Silver, $\mathrm{mg} / \mathrm{kg}$ & $<.5$ & $<.5$ & $<.5$ & $<.5$ \\
\hline Strontium, mg/kg & 200 & 200 & 180 & 190 \\
\hline Sulfur, \% & .06 & .06 & .06 & .07 \\
\hline Thallium, mg/kg & $<50$ & $<50$ & $<50$ & $<50$ \\
\hline Tin, $\mathrm{mg} / \mathrm{kg}$ & 4 & 3 & 4 & 4 \\
\hline Titanium, $\%$ & .49 & .49 & .48 & .48 \\
\hline Uranium, $\mathrm{mg} / \mathrm{kg}$ & $<50$ & $<50$ & $<50$ & $<50$ \\
\hline Vanadium, mg/kg & 130 & 130 & 130 & 130 \\
\hline Zinc, $\mathrm{mg} / \mathrm{kg}$ & 140 & 130 & 140 & 140 \\
\hline
\end{tabular}


Table A3. Percentage of silt and clay and constituent concentrations for bottom-sediment samples collected from core F-2B at coring site F-2 (fig. 2) in Fall River Lake, southeast Kansas, October 2006. - Continued

[Shading indicates concentration greater than threshold-effects guideline listed in table 3. >, greater than; mg/kg, milligrams per kilogram; \%, percent dry weight; <, less than]

\begin{tabular}{|c|c|c|c|c|}
\hline \multirow{2}{*}{$\begin{array}{c}\text { Constituent and unit of } \\
\text { measurement }\end{array}$} & \multicolumn{4}{|c|}{ Constituent concentration } \\
\hline & Interval 9 & Interval 10 & Interval 11 & $\begin{array}{c}\text { Interval } 12 \text { (top of } \\
\text { core) }\end{array}$ \\
\hline Percentage of silt and clay & $>99$ & $>99$ & $>99$ & $>99$ \\
\hline \multicolumn{5}{|c|}{ Nutrients } \\
\hline Total nitrogen, $\mathrm{mg} / \mathrm{kg}$ & 2,000 & 2,000 & 2,000 & 2,000 \\
\hline Total phosphorus, mg/kg & 830 & 850 & 860 & 910 \\
\hline \multicolumn{5}{|c|}{ Carbon } \\
\hline Carbon (total organic), $\%$ & 1.6 & 1.7 & 1.7 & 1.8 \\
\hline Carbon (total), $\%$ & 2.1 & 2.2 & 2.3 & 2.3 \\
\hline \multicolumn{5}{|c|}{ Trace elements } \\
\hline Aluminum, $\%$ & 9.9 & 10.0 & 9.8 & 9.9 \\
\hline Antimony, mg/kg & .8 & .7 & .8 & .7 \\
\hline Arsenic, mg/kg & 13 & 13 & 13 & 13 \\
\hline Barium, mg/kg & 610 & 610 & 610 & 610 \\
\hline Beryllium, mg/kg & 3.0 & 3.1 & 3.0 & 3.0 \\
\hline Cadmium, mg/kg & .4 & .5 & .5 & .5 \\
\hline Chromium, mg/kg & 100 & 100 & 100 & 100 \\
\hline Cobalt, $\mathrm{mg} / \mathrm{kg}$ & 17 & 18 & 18 & 18 \\
\hline Copper, mg/kg & 26 & 26 & 25 & 26 \\
\hline Iron, $\%$ & 5.0 & 5.0 & 5.0 & 5.0 \\
\hline Lead, mg/kg & 31 & 30 & 29 & 29 \\
\hline Lithium, mg/kg & 73 & 74 & 71 & 73 \\
\hline Manganese, $\mathrm{mg} / \mathrm{kg}$ & 970 & 1,000 & 1,100 & 1,100 \\
\hline Molybdenum, mg/kg & $<1$ & $<1$ & $<2$ & $<1$ \\
\hline Nickel, mg/kg & 45 & 45 & 44 & 45 \\
\hline Selenium, mg/kg & .7 & .7 & .7 & .6 \\
\hline Silver, $\mathrm{mg} / \mathrm{kg}$ & $<.5$ & $<.5$ & $<1.0$ & $<.5$ \\
\hline Strontium, $\mathrm{mg} / \mathrm{kg}$ & 180 & 190 & 180 & 180 \\
\hline Sulfur, $\%$ & .06 & .08 & .08 & .07 \\
\hline Thallium, mg/kg & $<50$ & $<50$ & $<100$ & $<50$ \\
\hline Tin, mg/kg & 3 & 5 & 4 & 5 \\
\hline Titanium, \% & .48 & .48 & .48 & .48 \\
\hline Uranium, mg/kg & $<50$ & $<50$ & $<100$ & $<50$ \\
\hline Vanadium, mg/kg & 130 & 130 & 130 & 130 \\
\hline Zinc, $\mathrm{mg} / \mathrm{kg}$ & 130 & 140 & 130 & 130 \\
\hline
\end{tabular}


Table A4. Percentage of silt and clay and constituent concentrations for bottom-sediment samples collected from coring site F-4 (fig. 2) in Fall River Lake, southeast Kansas, October 2006.

[Shading indicates concentration greater than threshold-effects guideline listed in table 3. >, greater than; $\mathrm{mg} / \mathrm{kg}$, milligrams per kilogram; \%, percent dry weight; <, less than]

\begin{tabular}{|c|c|c|c|}
\hline \multirow{2}{*}{$\begin{array}{c}\text { Constituent and unit of } \\
\text { measurement }\end{array}$} & \multicolumn{3}{|c|}{ Constituent concentration } \\
\hline & $\begin{array}{c}\text { Interval } 1 \text { (bottom of } \\
\text { core) }\end{array}$ & Interval 2 & $\begin{array}{c}\text { Interval } 3 \text { (top of } \\
\text { core) }\end{array}$ \\
\hline Percentage of silt and clay & $>99$ & $>99$ & $>99$ \\
\hline \multicolumn{4}{|c|}{ Nutrients } \\
\hline Total nitrogen, $\mathrm{mg} / \mathrm{kg}$ & 2,000 & 2,000 & 2,000 \\
\hline Total phosphorus, $\mathrm{mg} / \mathrm{kg}$ & 780 & 800 & 850 \\
\hline \multicolumn{4}{|c|}{ Carbon } \\
\hline Carbon (total organic), $\%$ & 1.6 & 1.6 & 1.7 \\
\hline Carbon (total), $\%$ & 2.2 & 2.2 & 2.4 \\
\hline \multicolumn{4}{|c|}{ Trace elements } \\
\hline Aluminum, $\%$ & 9.3 & 9.3 & 9.2 \\
\hline Antimony, mg/kg & .7 & .7 & .7 \\
\hline Arsenic, mg/kg & 12 & 12 & 12 \\
\hline Barium, mg/kg & 610 & 600 & 610 \\
\hline Beryllium, mg/kg & 2.8 & 2.9 & 2.9 \\
\hline Cadmium, mg/kg & .4 & .4 & .4 \\
\hline Chromium, mg/kg & 94 & 95 & 95 \\
\hline Cobalt, $\mathrm{mg} / \mathrm{kg}$ & 16 & 17 & 18 \\
\hline Copper, $\mathrm{mg} / \mathrm{kg}$ & 25 & 25 & 25 \\
\hline Iron, $\%$ & 4.6 & 4.6 & 4.6 \\
\hline Lead, $\mathrm{mg} / \mathrm{kg}$ & 30 & 29 & 28 \\
\hline Lithium, mg/kg & 66 & 66 & 65 \\
\hline Manganese, $\mathrm{mg} / \mathrm{kg}$ & 1,000 & 1,000 & 1,200 \\
\hline Molybdenum, mg/kg & $<1$ & $<1$ & $<1$ \\
\hline Nickel, mg/kg & 40 & 42 & 41 \\
\hline Selenium, mg/kg & 6 & .6 & 6 \\
\hline Silver, $\mathrm{mg} / \mathrm{kg}$ & $<.5$ & $<.5$ & $<.5$ \\
\hline Strontium, mg/kg & 200 & 190 & 190 \\
\hline Sulfur, \% & .05 & .06 & .06 \\
\hline Thallium, mg/kg & $<50$ & $<50$ & $<50$ \\
\hline Tin, mg/kg & 3 & 5 & 3 \\
\hline Titanium, $\%$ & .47 & .48 & .48 \\
\hline Uranium, mg/kg & $<50$ & $<50$ & $<50$ \\
\hline Vanadium, mg/kg & 120 & 120 & 120 \\
\hline Zinc, $\mathrm{mg} / \mathrm{kg}$ & 130 & 120 & 130 \\
\hline
\end{tabular}


Table A5. Percentage of silt and clay and constituent concentrations for bottomsediment samples collected from coring site F-5 (fig. 2) in Fall River Lake, southeast Kansas, October 2006

[Shading indicates concentration greater than threshold-effects guideline listed in table 3. >, greater than; $\mathrm{mg} / \mathrm{kg}$, milligrams per kilogram; \%, percent dry weight; <, less than]

\begin{tabular}{|c|c|c|c|}
\hline \multirow{2}{*}{$\begin{array}{c}\text { Constituent and unit of } \\
\text { measurement }\end{array}$} & \multicolumn{3}{|c|}{ Constituent concentration } \\
\hline & $\begin{array}{c}\text { Interval } 1 \text { (bottom } \\
\text { of core) }\end{array}$ & Interval 2 & $\begin{array}{c}\text { Interval } 3 \text { (top of } \\
\text { core) }\end{array}$ \\
\hline Percentage of silt and clay & $>99$ & $>99$ & $>99$ \\
\hline \multicolumn{4}{|c|}{ Nutrients } \\
\hline Total nitrogen, mg/kg & 2,000 & 2,000 & 2,000 \\
\hline Total phosphorus, mg/kg & 740 & 750 & 730 \\
\hline \multicolumn{4}{|c|}{ Carbon } \\
\hline Carbon (total organic), $\%$ & 1.5 & 1.6 & 1.5 \\
\hline Carbon (total), \% & 2.3 & 2.5 & 2.5 \\
\hline \multicolumn{4}{|c|}{ Trace elements } \\
\hline Aluminum, $\%$ & 8.2 & 8.2 & 7.6 \\
\hline Antimony, mg/kg & 6 & .7 & 6 \\
\hline Arsenic, mg/kg & 9.6 & 9.5 & 8.4 \\
\hline Barium, mg/kg & 590 & 580 & 560 \\
\hline Beryllium, mg/kg & 2.6 & 2.6 & 2.4 \\
\hline Cadmium, mg/kg & .4 & .4 & .4 \\
\hline Chromium, mg/kg & 85 & 85 & 79 \\
\hline Cobalt, mg/kg & 16 & 16 & 15 \\
\hline Copper, mg/kg & 23 & 23 & 22 \\
\hline Iron, $\%$ & 4.0 & 4.0 & 3.8 \\
\hline Lead, mg/kg & 29 & 27 & 25 \\
\hline Lithium, mg/kg & 56 & 57 & 54 \\
\hline Manganese, mg/kg & 890 & 850 & 800 \\
\hline Molybdenum, mg/kg & $<1$ & $<1$ & $<1$ \\
\hline Nickel, mg/kg & 37 & 37 & 34 \\
\hline Selenium, mg/kg & .6 & .6 & .5 \\
\hline Silver, $\mathrm{mg} / \mathrm{kg}$ & $<.5$ & $<.5$ & $<.5$ \\
\hline Strontium, mg/kg & 190 & 190 & 190 \\
\hline Sulfur, \% & .05 & .06 & .07 \\
\hline Thallium, mg/kg & $<50$ & $<50$ & $<50$ \\
\hline Tin, mg/kg & 4 & 4 & 2 \\
\hline Titanium, $\%$ & .50 & .48 & .47 \\
\hline Uranium, mg/kg & $<50$ & $<50$ & $<50$ \\
\hline Vanadium, mg/kg & 110 & 110 & 100 \\
\hline Zinc, $\mathrm{mg} / \mathrm{kg}$ & 110 & 110 & 100 \\
\hline
\end{tabular}


Table A6. Diatom species, number of valves counted, and relative percentage abundance in bottomsediment samples collected from core F-2B at coring site F-2 (fig. 2) in Fall River Lake, southeast Kansas, October 2006.

\begin{tabular}{|c|c|c|c|}
\hline $\begin{array}{c}\text { Depth of sample } \\
\text { (inches) }\end{array}$ & Species & $\begin{array}{c}\text { Number of valves } \\
\text { counted }\end{array}$ & $\begin{array}{c}\text { Relative percentage } \\
\text { abundance }\end{array}$ \\
\hline \multirow[t]{18}{*}{$0-6.3$} & Aulacoseira alpigena & 96 & 16.0 \\
\hline & Aulacoseira ambigua & 101 & 16.8 \\
\hline & Aulacoseira granulata & 362 & 60.3 \\
\hline & Cyclotella meneghiniana & 2 & .3 \\
\hline & Cyclotella stelligera & 6 & 1.0 \\
\hline & Diploneis oblongella & 2 & .3 \\
\hline & Fragilaria vaucheriae & 1 & .2 \\
\hline & Gomphonema drutelingense & 2 & .3 \\
\hline & Navicula capitatoradiata & 1 & .2 \\
\hline & Navicula reichardtiana & 1 & .2 \\
\hline & Navicula rostellata & 3 & .5 \\
\hline & Nitzschia gracilis & 2 & .3 \\
\hline & Nitzschia modesta & 2 & .3 \\
\hline & Nitzschia recta & 2 & .3 \\
\hline & Stephanodiscus hantzschii & 2 & .3 \\
\hline & Stephanodiscus medius & 9 & 1.5 \\
\hline & Stephanodiscus niagarae & 5 & .8 \\
\hline & $\begin{array}{l}\text { Synedra delicatissima var. } \\
\text { angustissima }\end{array}$ & 1 & .2 \\
\hline Total & & 600 & ${ }^{1} 100$ \\
\hline \multirow[t]{6}{*}{$6.3-12.7$} & Aulacoseira alpigena & 12 & 46.2 \\
\hline & Aulacoseira ambigua & 2 & 7.7 \\
\hline & Aulacoseira granulata & 7 & 26.9 \\
\hline & Gomphonema drutelingense & 2 & 7.7 \\
\hline & Gyrosigma acuminatum & 2 & 7.7 \\
\hline & Stephanodiscus niagarae & 1 & 3.8 \\
\hline Total & & 26 & ${ }^{1} 100$ \\
\hline $12.7-19.0$ & Aulacoseira granulata & 1 & 100 \\
\hline Total & & 1 & 100 \\
\hline $19.0-25.3$ & Aulacoseira granulata & 1 & 100 \\
\hline Total & & 1 & 100 \\
\hline
\end{tabular}


Table A6. Diatom species, number of valves counted, and relative percentage abundance in bottomsediment samples collected from core F-2B at coring site F-2 (fig. 2) in Fall River Lake, southeast Kansas, October 2006.-Continued

\begin{tabular}{|c|c|c|c|}
\hline $\begin{array}{l}\text { Depth of sample } \\
\text { (inches) }\end{array}$ & Species & $\begin{array}{c}\text { Number of valves } \\
\text { counted }\end{array}$ & $\begin{array}{c}\text { Relative percentage } \\
\text { abundance }\end{array}$ \\
\hline $25.3-31.7$ & Aulacoseira granulata & 2 & 100 \\
\hline Total & & 2 & 100 \\
\hline $31.7-38.0$ & No diatoms & 0 & 0 \\
\hline Total & & $\mathbf{0}$ & $\mathbf{0}$ \\
\hline $38.0-44.3$ & No diatoms & 0 & 0 \\
\hline Total & & $\mathbf{0}$ & $\mathbf{0}$ \\
\hline $44.3-50.7$ & No diatoms & 0 & 0 \\
\hline Total & & $\mathbf{0}$ & $\mathbf{0}$ \\
\hline $50.7-57.0$ & No diatoms & 0 & 0 \\
\hline Total & & $\mathbf{0}$ & $\mathbf{0}$ \\
\hline $57.0-63.3$ & No diatoms & 0 & 0 \\
\hline Total & & $\mathbf{0}$ & $\mathbf{0}$ \\
\hline $63.3-69.7$ & Aulacoseira granulata & 1 & 100 \\
\hline Total & & 1 & 100 \\
\hline \multirow[t]{13}{*}{$69.7-76.0$} & Aulacoseira alpigena & 142 & 27.5 \\
\hline & Aulacoseira ambigua & 25 & 4.8 \\
\hline & Aulacoseira granulata & 302 & 58.5 \\
\hline & Cyclotella meneghiniana & 5 & 1.0 \\
\hline & Cyclotella stelligera & 10 & 1.9 \\
\hline & Cymbella tumida & 1 & .2 \\
\hline & Diploneis oblongella & 1 & .2 \\
\hline & Fragilaria vaucheriae & 2 & .4 \\
\hline & Gyrosigma acuminatum & 2 & .4 \\
\hline & Navicula capitatoradiata & 3 & .6 \\
\hline & Nitzschia recta & 2 & .4 \\
\hline & Stephanodiscus medius & 20 & 3.9 \\
\hline & $\begin{array}{l}\text { Synedra delicatissima var. } \\
\text { angustissima }\end{array}$ & 1 & .2 \\
\hline Total & & 516 & ${ }^{1} 100$ \\
\hline
\end{tabular}

${ }^{1}$ Number rounded to account for rounding errors in the individual species percentages. 
Publishing support provided by:

Rolla Publishing Service Center

For more information concerning this publication, contact:

Director, USGS Kansas Water Science Center

4821 Quail Crest Place

Lawrence, KS 66049

(785) 842-9909

Or visit the Kansas Water Science Center Web site at: http://ks.water.usgs.gov 
Back cover. Map showing land use within the Fall River Lake drainage basin (fig. 1 in this report). Land use data from Kansas Applied Remote Sensing Program, Data Access and Support Center, 1993. 


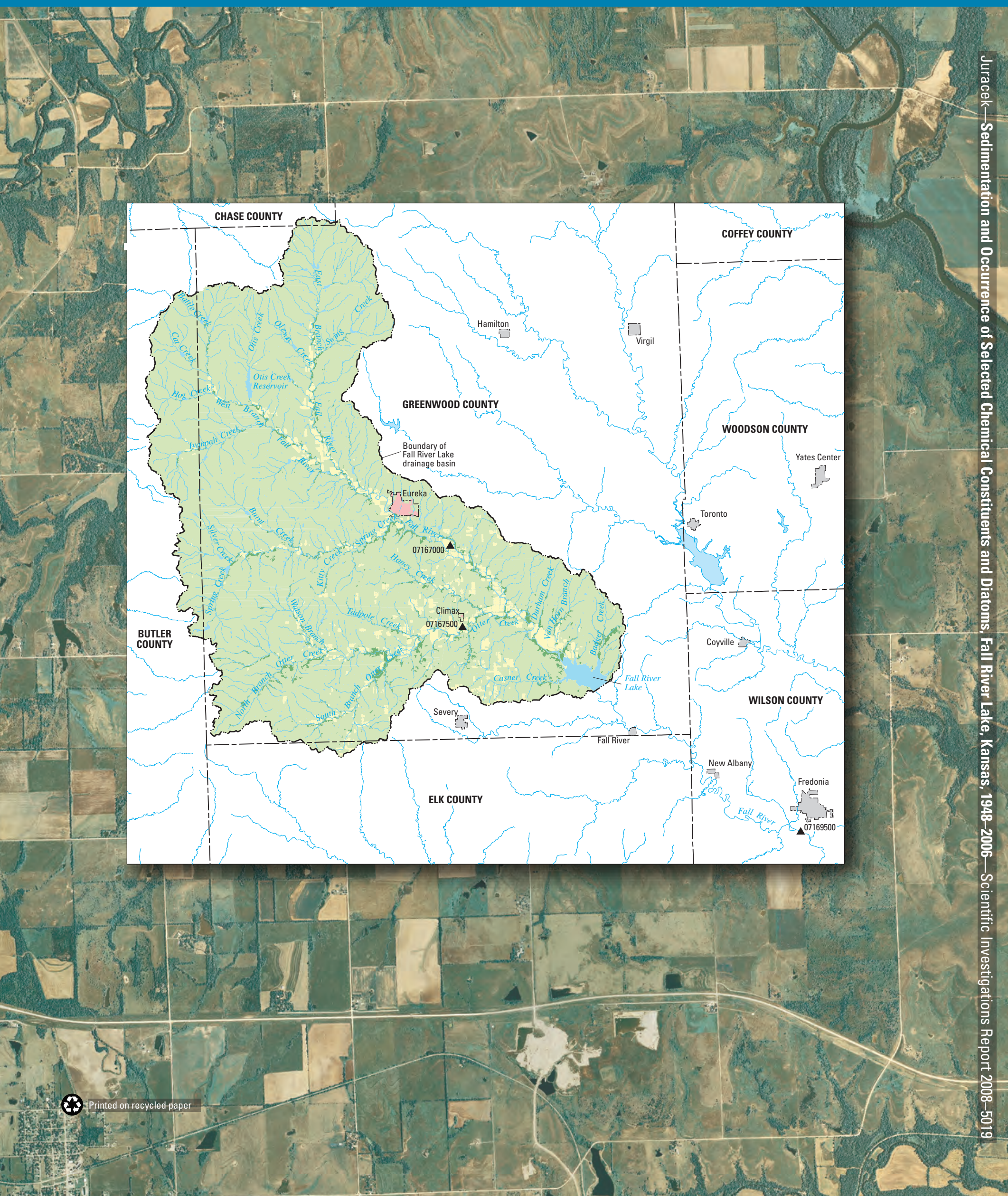

